Fabian Eggers, Isabella Hatak, Sascha Kraus, Thomas Niemand

\title{
Technologies that support marketing and market development in SMEs - Evidence from social networks
}

Journal of Small Business Management

\begin{abstract}
This study builds on previous research on information technology implementation and usage in SMEs and applies a special focus on social networks. Specifically, this research investigates antecedents of social network usage in SMEs and respective performance outcomes. The results show that entrepreneurial orientation is positively related to social network usage in SMEs, whereas responsive market orientation shows no effect. Social network usage is not directly related to SME growth; yet, it mediates the relationship between entrepreneurial orientation and SME growth. Interestingly, large firms show the opposite effects regarding antecedents and performance-related consequences of social network usage.
\end{abstract}

Keywords: Social Network Marketing, Social Media, SMEs, Technology Implementation, Entrepreneurial Orientation, Responsive Market Orientation

\section{Introduction}

The positive performance effect of information technology implementation and usage on firm performance has been confirmed by several studies (see e.g., Petter, DeLone, and McLean 2008; Sabherwal, Jeyaraj, and Chowa 2006). Whereas most studies have been conducted in a large firm context, Johnston et al. (2007) confirm that the implementation of information and communication technologies is also beneficial for SMEs. However, certain factors exist that influence and potentially inhibit technology implementation and usage by SMEs.

Internal factors are attitudes towards and knowledge of the CEO/owner manager about information technology implementation and usage, organizational context such as technological and 
human resource infrastructure (see e.g., Bharadwaj, and Soni 2007; Caldeira, and Ward 2002; Thong 1999), financial capacities (Kannabiran, and Dharmalingam 2012; Nguyen 2009), firm size and growth (see e.g., Malaquias, and Hwang 2015; Nguyen, Newby, and Macaulay 2015; Premkumar 2003), and strategic orientation of the firm such as innovative capabilities (see e.g., Dyerson, Spinelli, and Harindranath 2016; Fillis, Johansson, and Wagner 2003; Lee, and Runge 2001). External factors shaping technology usage in the SME context consist of competitive pressures (see e.g., Bruque, and Moyano 2007; Kannabiran, and Dharmalingam 2012; Nguyen 2009), external support (see e.g., Solomon, and Perry 2011; Solomon, Bryant, May, and Perry 2013; Thong 2001), and social expectations of information technology use (see e.g., Lee, and Runge 2001; Nguyen, Newby, and Macaulay 2015; Riemenschneider, Harrison, and Mykytyn 2003).

Since there is a variety of factors shaping the implementation and usage of information technologies in the SME context, there is reason to believe that the special characteristics of SMEs also influence the implementation and usage of social media technologies (Bulearca, and Bulearca 2010; Keel, and Bernet 2013). As an internet-based application (Kaplan, and Haenlein 2010, p. 61), social media "provides a way people share ideas, content, thoughts and relationships online" (Scott 2009, p. 38). This online engagement can take on various designs from simple interaction (e.g., blogs, chats) over collaboration to cocreation (e.g., tagging, content editing; Aral, Dellarocas, and Godes 2013), primarily applied in social networking sites. Such social networks (e.g., Facebook, MySpace, Twitter, LinkedIn or XING - the European pendant to LinkedIn) allow individuals and groups to connect with each other and build networks based on a personal or company profile, resulting in considerable changes in the communications landscape (Kietzmann, Hermkens, McCarthy, and Silvestre 2011). In fact, using social networks enables firms to more actively engage consumers than traditional communication approaches (see e.g. Castronovo, and Huang 2012; Hoffman, and Fodor 2010; Trusov, Bucklin, and Pauwels 2009). Consequently, recent paradigm shifts in marketing such as the service dominant logic (Vargo, and Lusch 2004) or the relationship marketing perspective (Gummesson, Mele, Polese, Gummesson, and Grönroos 2012) point towards the need for using social media as communication tool. This is particularly the case in light of the potential to share timely and relevant information with stakeholders and to shift the focus from products to consumers. As a result, in 2015, 78\% of the U.S. Fortune 500 companies used Twitter, 74\% Facebook, and 21\% blogging tools (Barnes, Lescault, and Holmes 2015). In Switzerland, as an example in the German-speaking countries under investigation in this study, almost all 
large companies (89\%) were active social media users in 2013, whereas only 59\% of all SMEs used this technology (Keel, and Bernet 2013).

In this regard, a few studies exist that encourage the notion that social media usage and respective performance impacts differ between SMEs and large firms. Moran (2009) as well as Chua, Deans, and Parker (2009) point out that SMEs do not have the necessary resources to use social media effectively. Moreover, in compliance with the results regarding information technology use in general, SMEs are often managed by a single dominant owner/manager (Tocher, and Rutherford 2009) who might lack knowledge about social media marketing and is usually involved in numerous aspects of management. In this regard, centralized power structures and a lack of formalized and sophisticated strategic planning (Williamson, Cable, and Aldrich 2002) might inhibit the development and execution of successful social network marketing strategies. At the same time, SMEs appear to understand the importance of social media as a marketing tool better than large companies (George, and Simon 2011). Given their smaller scale, SMEs are supposed to be able to use customer insights faster (Nakara, Benmoussa, and Jaouen 2012) and more effectively than large companies (Carter 2011; Wickert, and Herschel 2001). That is, we find contradicting results regarding the antecedents and effectiveness of social media marketing in SMEs.

Given this heterogeneity in terms of empirical findings, this study aims to develop a more fine-grained understanding of the antecedents and performance-related consequences of information technology usage in SMEs, with an emphasis on social network usage. With regard to antecedents, earlier studies found that especially the strategic orientation of firms influences the implementation and use of information technologies (see e.g., Dyerson, Spinelli, and Harindranath 2016; Fillis, Johansson, and Wagner 2003; Lee, and Runge 2001). Two strategic orientations that are particularly suited to explain behavioral firm-level outcomes are entrepreneurial orientation (EO) and responsive market orientation (RMO) (Baker, and Sinkula 2009; Eggers, Kraus, Hughes, Laraway, and Snycerski 2013; Hakala 2011). We believe that SMEs possessing high levels of EO and RMO might be more active in using social networking sites, using those to exploit new and innovative opportunities (Fischer, and Reuber 2011), ultimately leading to increasing firm growth (Macpherson, and Holt 2007). We therefore investigate the relationship between social network usage and SME growth as an indicator of firm performance. All postulated relationships will be analyzed by taking account of contingencies such as industry and customer type. Both, EO and RMO as antecedents of social network usage, as well as the link between social network usage and 
SME growth have not been jointly investigated in previous studies. We aim to fill this research gap through a quantitative research design of 411 companies in German-speaking countries as we additionally contrast social network usage of SMEs with large companies to better understand the specificities associated with firm size.

\section{Theoretical Background}

\section{Literature Review}

We conducted a systematic literature review of performance-related outcomes and antecedents of social media usage to shed more light on this fast-paced research field. The databases ABI/INFORM Complete, Science Direct and Business Source Complete (EBSCO) were used to cover the time frame from 2013 until 2015. We performed two systematic searches in each database using the following search strings to search abstracts, titles, and keywords: 1) "social media" AND "firm size" as well as 2) "social media" AND "firm performance" OR "social media" AND "business performance." We deliberately refrained from including "SME" and related search terms to obtain a holistic literature perspective that allows conclusions to be derived regarding the relevance of SMEs in the social media literature. Excluding papers that did not fit the business research context led to a reduction in the number of academic articles from 56 to 37 (see complete list in the appendix). The literature review revealed only four studies that focus on SMEs. The results of this review are combined with earlier research contributions to further illustrate this research gap. Unless otherwise noted, the following studies were either conducted among large firms or do not distinguish between different firm sizes.

In terms of the performance effect of social media technology usage, the majority of identified studies focuses on "soft" performance outcomes. In other words, the outcome of social media is assessed as the number of "likes" on e.g. a product page or as increased brand credibility (Coulter, and Roggeveen 2012; Christodoulides 2009). This includes better monitoring of brand images, more motivated customers (Aquino 2012), and stronger purchase intentions (Colliander, and Dahlen 2011; Hutton, and Fosdick 2011). In addition, increased message reach, and decreased contact costs (Kirchgeorg, Ermer, Brühe, and Hartmann 2009) as well as enhanced customer loyalty are used as performance measures in social media technology studies (Gummerus, Liljander, 
Weman, and Pihlstrom 2012; Lipsman, Mudd, Rich, and Bruich 2012; Weinberg, and Pehlivan 2011).

A number of studies also make the connection between social media technology usage and "hard" performance effects, including financial performance and/or firm growth. Gecti and Dastan (2013) illustrate that social media usage positively affects business turnover, with this relationship being mediated by marketing cost savings and marketing-based outputs such as increased brand recognition and customer loyalty. Martinez-Nunez and Pérez-Aguiar (2014) find a positive relationship between the usage of online social networks and sales as well as pre-tax profits. Qu, Wang, Wang, and Zhang (2013) show that certain online retailers' social activities on e-commerce platforms improve a firm's revenue and transaction volume. Also, an effective management of online reviews affects firm performance in the hospitality industry, measured as the average daily rate and revenue per available room (Kim, Lim, and Brymer 2015). Jiang, Tadikamalla, Shang, and Zhao (2016) show that electronic word-of-mouth has a significant effect on a brand's market share. The number of "followers" and "likes" positively influence a firm's share value (Paniagua, and Sapena 2014), and social media technology usage is associated with increased stock price and return on assets (Du, and Jiang 2015). In this regard, two additional studies report that social media usage leads to increased stock performance (Schniederjans, Cao, and Schniederjans 2013; Yu, Duan, and Cao 2013). However, Jiang, Tadikamalla, Shang, and Zhao (2014) show that only social media behaviors of certain stakeholder groups can increase a firm's share value. With regard to firm size, Nickell, Rollins, and Hellman (2013) find that social media use does not discriminate between high and low performing firms.

We identified three studies that are noteworthy for the SME context. Kudeshia, Sikdar, and Mittal (2016) analyze the effectiveness of social media technology as a communication tool for SMEs and small scale entrepreneurs. They find that "Facebook likes" are converted into word-ofmouth, which results in increased purchase intentions. Michaelidou, Siamagka, and Christodoulides (2011) research SMEs in business-to-business environments and find that social networks are mainly used to achieve brand objectives, and that an overwhelming majority of users do not adopt any metrics to assess their effectiveness. Zaglia, Waiguny, Abfalter and Mueller (2014) find in their study on CEOs of SMEs that trust in social networks, access to resources provided through social network memberships, and perceived value of social networking technologies lead 
to satisfaction with their usage and increase the intention of recommending social networks to other business partners. These outcomes are largely mediated by firm growth.

In terms of antecedents of social media usage, only a few studies researched the conditions contributing to the intention to implement and the actual usage of social media technology, such as individual personal motivations, attitudes towards the medium, experience, or perceived popularity (Fitzgerald, Kruschwitz, Bonnet, and Welch 2014; Lee, and Cho 2011; Sledgianowski, and Kulviwat 2009). Our literature review revealed one study with a focus on SMEs that identified IT infrastructure capability, competitor pressure, marketing, and innovation management capabilities as key mechanisms through which small firms learn to develop a social media competence (Braojos-Gomez, Benitez-Amado, and Javier Llorens-Montes 2015). In a large firm context, Seo and Lee (2016) find that concurrently preparing both technological and organizational initiatives is important for social media technology usage, along with a correct and precise understanding of the firm's core value proposition. Schultz, Schwepker, and Good (2012) propose and empirically assess a model of social media usage among business-to-business salespeople, finding that the age of the salesperson negatively affects social media usage, while social media norms positively affect it. Customer-oriented selling was not found to be positively related to social media usage, although it does have a positive effect on sales performance. In contrast, Harrigan, Soutar, Choudhury, and Lowe (2015) show that an underlying customer relationship orientation is needed to drive social media technology use and customer engagement initiatives.

In sum, several studies exist that focus on the performance impact of social media technology usage. However, only a few deal with antecedents or explicitly consider the special characteristics and challenges of social media technology use in the context of SMEs. Only one study (Braojos-Gomez, Benitez-Amado, and Javier Llorens-Montes 2015) deals with antecedents of SMEs' social media usage. The remaining studies focusing on social media usage in SMEs are largely descriptive (Chua, Deans, and Parker 2009; Derham, Cragg, and Morrish 2011) or case-based and anecdotal (Harris, and Rae 2009; Öztamur, and Karakadilar 2014; Pentina, and Koh 2012; Stockdale, Ahmed, and Scheepers 2012). Although several studies assessed the direct effect of social media usage on financial performance and firm growth, none of these studies were conducted in an SME context. This is particularly interesting because firm growth is considered one of the most important goals for SMEs and the most commonly used performance indicator in entrepreneurship and strategy research (Carton, and Hofer 2006). So, research is largely missing regarding 
a firm foundation on which SMEs can base strategic decisions that concern the usage of social media technology as a marketing tool (Hoffman, and Novak 2012).

In order to resolve this opaqueness, this study focuses on the applicability of social network usage as social media technology in SMEs for three reasons. First, there is disagreement in the literature about what communication tools meet the characteristics of social media (see e.g. Constantinides, and Fountain 2008; Kaplan, and Haenlein 2010; Vernuccio 2014). Second, social networking plays a central role in the realm of social media (Hennig-Thurau, Malthouse, Friege, Gensler, Lobschat, Rangaswamy, and Skiera 2010). Third, social networking sites typically include a wide range of features, combining the functions of other social media sites such as content sharing communities or blogs (Enders, Hungenberg, Denker, and Mauch 2008).

\section{Development of Hypotheses}

EO is used in the entrepreneurship and strategy literature to describe the strategic management style of firms with entrepreneurial tendencies (Lyon, Lumpkin, and Dess 2000). Although additional aspects of EO have been suggested in the literature (most notably autonomy and competitive aggressiveness), a general commonality among conceptualizations is the inclusion of innovativeness, risk-taking, and proactiveness as central dimensions to define entrepreneurial strategic processes and firm-level behaviors (Covin, and Slevin 1991; Lumpkin, and Dess 1996). Innovativeness reflects a firm's willingness to support new ideas, creativity, and experimentation in the development of internal solutions or external offerings. Proactiveness represents a forward-looking and opportunity-seeking perspective that provides an advantage over competitors' actions by anticipating future market demands. Risk-taking is associated with a firm's readiness to make bold and daring resource commitments towards organizational initiatives with uncertain returns (Miller 1983).

Because proactive firms tend to adapt new technologies earlier than their competitors (Lumpkin, and Dess 1996), it can be suggested that they have a stronger tendency to use social networking technologies to uncover and satisfy unarticulated customer needs. In this regard, Bruque and Moyano (2007) found that an SME's proactive orientation leads to technological change. Furthermore, social networks help them not only analyze current customer needs, but also investigate future trends. Gaining new knowledge by listening to the crowd (Harris, Rae, and Grewal 2008) and discussing ideas offers the possibility to find new ideas and evaluate products 
(Mangold, and Faulds 2009). Michaelidou, Siamagka and Christodoulides (2011) show that organizational innovativeness is associated with social media usage. This finding is in line with previous literature where the SME owner's innovativeness is positively correlated with information technology implementation (Lee, and Runge 2001; Thong 1999). Also, a study by Braojos-Gomez, Benitez-Amado, and Llorens-Montes (2015) reveals that innovativeness enables SMEs to develop a social media competence. However, using social networks as a marketing tool can also be a risky endeavor because best practices in the SME context are scarce. This might in turn lead to ineffective or even negative outcomes. Although actual social network usage comes at little or no cost, it must be remembered that the development of social networking campaigns can be costly because companies have to recruit and keep personnel with specific know-how, or outsource this task outright (Hoffman, and Fodor 2010; Schmidt, and Ralph 2011), which is a key issue for SMEs, typically being confronted with resource constraints. Furthermore, a company can encounter data privacy concerns (Steinman, and Hawkins 2010). SMEs that implement new technologies can therefore be characterized by a greater risk orientation (Peltier, Schibrowsky, and Zhao 2009). Thus, not only proactiveness and innovativeness, but also a calculated willingness to take risks is required to make use of social networking technologies. We therefore postulate:

H1: There is a positive relationship between SMEs' entrepreneurial orientation and their social network usage.

Along with EO, social network usage in SMEs can also be influenced by responsive market orientation. RMO is the customer-oriented part of the marketing orientation concept which can be defined as "the organization-wide generation of market intelligence pertaining to current and future needs of customers, dissemination of intelligence horizontally and vertically within the organization, and organization-wide action or responsiveness to market intelligence" (Kohli, Jaworski, and Kumar 1993, p. 467). Companies with a high RMO focus mainly on current, expressed customer needs and try to discover, understand, and satisfy these needs (Narver, Slater, and MacLachlan 2004).

Nguyen et al. (2015) show that in small businesses, customers are the main driving force of information technology implementation, with customer orientation driving social media technology usage (Harrigan, Soutar, Choudhury, and Lowe 2015). Especially social networks provide a valuable basis for analyzing immediate customer needs (Livingstone 2008). Customers join brand 
communities for discussing products and services, or even create own forums in which they interact with like-minded persons and share their knowledge (Arnone, Colot, Croquet, Geerts, and Pozniak 2010). This behavior results in the development of user-generated content, allowing companies to explore customers' needs and expectations in detail. SMEs with a high RMO will therefore engage in the opportunity to analyze shared consumer information and thereby improve their products and services based on the content generated through the use of social networking technologies. Therefore, we formulate:

H2: There is a positive relationship between SMEs' responsive market orientation and their social network usage.

As prior research advocates a positive link between social media technology usage and a firm's financial performance (e.g. Kim, Lim, and Brymer 2015; Martínez-Núñez, and Pérez-Aguiar 2014; Qu, Wang, Wang, and Zhang 2013), also in the SME context, the use of social networks may be particularly promising in terms of firm growth, which again depends on the use of managerial and entrepreneurial resources. While entrepreneurial resources are required for opportunity exploration, managerial resources are essential to provide systems and processes to enable opportunity exploitation (Macpherson, and Holt 2007). However, for SMEs with their resource constraints (Wiklund, and Shepherd 2003), it is often not possible to engage in both exploration or exploitation, so most SMEs will be more oriented towards one of the two strategies (March 1991; Mitchell, and Singh 1993). We argue that SMEs should focus on exploitation to promote firm growth. Firms focusing on exploitation compete based on their existing products and services, emphasizing quality and efficiency (Gupta, Smith, and Shalley 2006). In this regard, SMEs must pursue the goal of reducing variability and achieving high process and quality improvements through standardization. Therefore, SMEs require managerial resources that emphasize the efficient execution of processes and procedures (Hatak, Kautonen, Fink, and Kansikas 2016), and social networks that allow them to bring promising market opportunities to fruition through direct and more intense interaction with customers as a result. Consequently, social network usage supports entrepreneurial actions, which are associated with firm growth in SMEs (Goffee, and Scase 1995; Fischer, and Reuber 2011). We therefore assume:

H3: There is a positive relationship between social network usage and firm growth in SMEs. 
Finally, along with analyzing EO and RMO as antecedents of social network usage, we also assess their direct growth impact. Many studies have investigated how a high EO leads to increased performance (e.g. Covin, and Slevin 1989; Lumpkin, and Dess 1996). Most noteworthy, the positive effect of EO on firm performance was confirmed by a meta-analysis by Rauch, Wiklund, Lumpkin, and Frese (2009) and with a specific focus on the SME context, for example by Kraus and colleagues (2012). In examining the causal relationship between EO and firm growth in SMEs and consistent with the resource-based view, EO is seen as an organizational posture that enables the structuration, bundling, and leveraging of resources toward entrepreneurial aims (Ireland, Hitt, and Simon 2003). According to Wiklund and Shepherd (2011), this posture is based on the notion that entrepreneurial strategy-making and processes represent a valuable, rare, and inimitable gestalt through which firms can develop a competitive advantage, which in turn promotes firm growth (Anderson, and Eshima 2013; Covin, Green, and Slevin 2006).

Also, previous studies have shown that companies that build their competitive strategy on the satisfaction of customer needs and that therefore constantly monitor the level of commitment and orientation to serving customers' needs show a positive performance outcome (Narver, and Slater 1990; Narver, Slater, and MacLachlan 2004). SMEs can specifically overcome their sizerelated disadvantages that distinguish them from large firms such as less market power or economies of scale by developing capabilities for closeness and responsiveness to market demands (e.g. Alpkan, Yilmaz, and Kaya 2007; Slater, and Narver 1998). Consequently, and according to a study by Pelham (2000), market-oriented SMEs are more likely to achieve superior firm performance especially if they follow a growth/differentiation strategy.

Although both relationships have been tested broadly in the past, we believe that given the interaction of our study variables, and for the purpose of achieving a sufficiently thorough research model, an analysis of the final two hypotheses in this specific context makes sense:

H4: There is a positive relationship between entrepreneurial orientation and firm growth in SMEs.

H5: There is a positive relationship between responsive market orientation and firm growth in SMEs. 


\section{Methodology}

\section{Sample}

Data was collected by drawing a random sample of companies in the four German-speaking countries of Austria, Germany, Liechtenstein and the German-speaking part of Switzerland. Following a "key informant approach" (Lechner, Dowling, and Welpe 2006), CEOs and top-level managers from marketing and sales departments as the primary source of relevant knowledge and information (Lechner, Dowling, and Welpe 2006) with regard to our study context were contacted directly via email. A summary of the results was offered as an incentive for taking part in the study.

As the survey was geared towards non-English-speaking business executives, the entire questionnaire was subjected to double-blind translation and back-translation of the measuring instruments by two groups of independent translators (Brislin 1980). If questions did not have the same meaning after the back-translation, the translators discussed the problem and agreed on a new wording for the question. Before conducting the survey, all translations were compared again with the original sources to identify and correct errors that may have arisen from interpretation differences.

To ensure that the questionnaire was understandable and valid, a pre-test with 21 respondents that were similar to the target group was conducted (Hunt, Sparkman Jr, and Wilcox 1982). This number corresponds with the views of Ferber and Verdoorn (1962) or of Boyd, Westfal and Stasch (1977) that 12 or 20 test persons (respectively) are sufficient as a pre-test sample. The results of the first pre-test were analyzed, and the questionnaire was adjusted. This was followed by a second pre-test with 14 respondents to validate the adjusted questions. The questionnaire was found to be satisfactory once this was done.

Data was selected from major company databases to generate a representative sample with 1,000 addresses randomly picked in each country. The Swiss Schober database was used for data collection in Switzerland and Liechtenstein. In Germany, the addresses were generated from the Hoppenstedt Company Database, while in Austria the Aurelia database was used. A total of 596 questionnaires were returned with 411 being fully completed. The response rate was $10.2 \%$ in 
Switzerland and Liechtenstein, $12.0 \%$ in Germany, and 18.9\% in Austria. The SME definition of the European Commission (2003) was used to distinguish SMEs $(n=339)$ from large companies $(n=72)$. A detailed overview of all sample statistics can be found in Table 1 .

$$
\text { +++ INSERT TABLE } 1 \text { ABOUT HERE +++ }
$$

\section{Measures}

Social network usage. Social network usage was measured through two items: "Number of social networks used" (Michaelidou, Siamagka, and Christodoulides 2011) and "Frequency of usage" (Kaplan, and Haenlein 2012). Frequency of usage ranged from "daily" to "weekly", "monthly", "quarterly", "semi-annually" to "yearly", and also included a "never" category.

Entrepreneurial and responsive market orientation. The questionnaire from Rigtering, Kraus, Eggers, and Jensen (2013), which is based on Miller's (1983) three main EO categories of innovativeness, proactiveness, and risk-taking, was used to measure EO. For RMO, the scale consisting of seven items by Narver, Slater, and MacLachlan (2004) was used.

Firm growth. Firm growth was assessed via the four sub-dimensions of growth in sales, profit, number of employees, and market share (following Chen, Tzeng, Ou, and Chang 2007). All items were assessed in relation to the competition. Statements regarding all three constructs (EO, RMO, and firm growth) were measured using a 5-point Likert scale ranging from "totally agree" to "totally disagree".

Control variables. Several control variables with regard to firm characteristics were used to assess representativeness of our dataset and the validity of our model. Control variables are 1) availability of monitoring mechanisms for measuring the effectiveness of social network usage, 2) industry affiliation (manufacturing or service), 3) customer type (B2B or B2C), and 4) family firm (family-owned business or not).

\section{Data Analysis}

Data was analyzed in step 1 through descriptive measures to achieve an overview of social network usage in different firm types. In step 2, covariance-based structural equation modeling (SEM) was used to test our hypotheses developed for the SME context and to further explore differences to 
large enterprises. SEM appears to be an adequate analysis instrument for two main reasons. First, our hypotheses create a complex pattern of interrelationships among variables with multiple ways to affect each other. Second, the suggested variables EO, RMO, social network usage, and firm growth represent higher-order constructs that cannot be captured with one single item and thus are subject to measurement error. For example, several survey items point towards risk orientation of the firm, and risk orientation itself is one element of the EO concept. In other words, we measure latent, unobserved variables with the help of observed survey items (Maruyama 1997). In order to control the measurement error and avoid method variance by applying related but different estimation methods, all hypotheses are tested within the SEM approach. In a third step, with regard to examining possible differences between SMEs and large firms in an explorative manner, we apply the SEM approach through two-group SEM modeling (Byrne, Shavelson, and Muthén 1989), linear regressions, and binary logit regressions.

\section{Results}

\section{Descriptive Analysis}

Our findings indicate that $62 \%$ of firms in the sample use social networking sites as a marketing tool. $21 \%$ of current non-users plan to start using social networks in the next two years. A difference was found in the social network usage of SMEs and large firms: Only 58\% of SMEs are active social network users, whereas $81 \%$ of all large firms use social networks for achieving their marketing objectives. Whereas only $19 \%$ of SME "non-users" plan to employ social networks in the next two years, it is $35 \%$ for large firms. A comparison between B2B and B2C oriented firms shows that there is only a small difference in usage. $60 \%$ of B2B firms are active social network users while $66 \%$ of all B2C firms use social networking technologies.

$$
+++ \text { INSERT TABLE } 2 \text { ABOUT HERE +++ }
$$

The results indicate that most firms use more than just one social network. Facebook (77\%) is the most used social network for marketing activities in the sample, followed by XING $(69 \%)$. A difference could be identified regarding the social network usage in SMEs and large firms. Whereas Facebook is the most popular social network among SMEs (44\%), have most large firms 
a presence on XING (76\%). Overall, it can be seen that every social network under consideration has a higher usage rate by large firms.

$$
\text { +++ INSERT TABLE } 3 \text { ABOUT HERE +++ }
$$

The researched firms show different behaviors of communication on social networks. Most of them (42\%) communicate messages on a weekly basis to their audience. $24 \%$ write messages or send pictures and videos every day, another $18 \%$ communicate on a monthly basis. In general, large firms tend to be more active on social networks than SMEs: $38 \%$ of them communicate everyday business-related news (20\% in SMEs). There are also some SMEs (5\%) that have a social network presence although they never use their profile.

\section{Reliability and Validity Checks}

SEM using a maximum likelihood estimator with a list-wise deletion of missing data was used to test our hypotheses (using lavaan 0.5-19 and related packages in $R$ ). We follow the paradigm by Gerbing and Anderson (1988) to ensure construct validity of our latent variables before interpreting the relationships between them. More specifically, after an assessment of factorial structure by exploratory factor analysis (EFA), reliability is evaluated by Cronbach's $\alpha$, followed by convergence and discriminant validity checks in a confirmatory factor analysis (CFA) as suggested by Fornell and Larcker (1981). CFA and SEM are applied as two-group comparisons to account for the expected differences between SMEs and large enterprises.

EFA results indicate that all four latent variables load on one factor each. Consequently, reliability was sufficient for social network usage ( $\alpha=.869)$, EO $(\alpha=.763), \operatorname{RMO}(\alpha=.701)$, and firm growth $(\alpha=.893)$. However, an initial CFA over both groups showed low loadings for the indicators "We freely communicate information about our successful and unsuccessful customer experiences across all business functions (RMO)" (.484) and "I believe this business exists primarily to serve customers (RMO)" (.440) as well as for "Last year we achieved a higher growth on number of employees than our (direct/indirect) competitors (firm growth)" (.472). Further, a twogroup CFA demonstrates that the indicator "We constantly monitor our level of commitment and orientation to serving customer needs (RMO)" even underscores the threshold of .4 in the large 
enterprises group (.322). For these reasons, we removed the respective indicators. Since all latent variables are supposed to be reflective, indicator removal is no danger to validity (Jarvis, MacKenzie, and Podsakoff 2003).

In a next step, convergent and discriminant validity are checked. Social network usage $\left(A V E_{S M E}=.694 ; A V E_{L E}=.701\right), \mathrm{EO}\left(A V E_{S M E}=.524 ; A V E_{L E}=.501\right)$, and firm growth $\left(A V E_{S M E}\right.$ $\left.=.810 ; A V E_{L E}=.601\right)$ fulfill the minimum threshold for convergent validity $(A V E>.5)$. Due to the extensive deletions for RMO, the explained variance is estimated below that threshold $\left(A V E_{S M E}\right.$ $\left.=.372 ; A V E_{L E}=.438\right)$. However, since substantial intercorrelations between the items and discriminant validity are given for all measures, we continue with all latent variables.

Table 4 depicts the measured variables' factor loadings on the latent variables in the final two-group CFA. Table 5 illustrates the two-group structural model. The model provided a reasonable to good fit with the data: $\mathrm{Chi}^{2}=171.322$ (d.f. $\left.=98\right), p<.001, \mathrm{CFI}=.962$, RMSEA $=.060$. For these fit measures, CFI values above .95 indicate a good-fitting model and RMSEA values below .08 indicate a reasonably good-fitting model (Keith 2006). Further, measurement invariance tests show small albeit significant differences in loadings $\left(\Delta C h i^{2}=19.366\right.$ with $\Delta d . f .=8$ and $p$ $<.05)$, intercepts $\left(\Delta C h i^{2}=38.946\right.$ with $\Delta$ d.f. $=8$ and $\left.p<.001\right)$, and means $\left(\Delta C h i^{2}=33.229\right.$ with $\Delta d . f .=4$ and $p<.001)$. Here, only small differences between models other than structural paths are present. Marginal differences in fit measures (loadings: $\triangle C F I=.006, \triangle R M S E A=.002$; intercepts: $\triangle C F I=.016, \triangle R M S E A=.008$; loadings: $\triangle C F I=.015, \triangle R M S E A=.007)$ confirm this assumption and lead to the conclusion that partial invariance is achieved. Hence, we continue with the comparison of the structural coefficients.

$$
+++ \text { INSERT TABLE } 4 \text { ABOUT HERE +++ }
$$

\section{Hypotheses Tests}

First, with regard to the relationship of EO and RMO to social network usage, results indicate that SMEs' social network usage is significantly improved by EO $(\beta=.421, p<.001)$, but not by RMO $(\beta=-.154, p>.05)$. With this being the case, for the SME context, we find support for H1, but not for H2. In addition, our two-group model indicates important results, with the $\mathrm{Z}$ test being used for differences in the structural estimates (Gonzalez, and Griffin 2001). Specifically, large enterprises 
that intensively use social networks are not significantly driven by $\mathrm{EO}(\beta=.151, p>.05)$, but by $\operatorname{RMO}(\beta=.221, p<.01)$.

Second, with regard to firm growth, results indicate that SMEs cannot improve their growth levels via a more intensive usage of social networks alone since the effect is not significant $(\beta=$ -.086, $p>.05)$. That is $\mathrm{H} 3$ is not supported in the SME context. In turn, large enterprises possess this option owing to the effect's significance $(\beta=.303, p<.01)$.

Third, we find that that the direct effect of EO and RMO on firm growth is confirmed for SMEs (EO: $\beta=.240$; RMO: $\beta=.237$; both: $p<.05$ ), providing support for $\mathrm{H} 4$ and H5. Due to the small sample size, both direct effects are insignificant in the large enterprise group (EO: $\beta=.221$; RMO: $\beta=.303$, both: $p>.05)$. However, difference tests and the comparative strength of the relationship across both groups indicate that there are no meaningful differences between SMEs and large firms.

Since the effect of EO and RMO on firm growth might be mediated via social network usage, an exploratory mediation analysis is conducted to shed light on the relationships among the latent variables. We thereby applied the two-group SEM approach of mediation analysis (Iacobucci, Saldanha, and Deng 2007). For SMEs, this analysis shows a mediation of EO via social network usage (direct effect: $b=.368,<.01$; indirect effect: $b=.450, p<.05$; total effect: $b=.404, p$ $<.05$ ), but none of RMO through social network usage (direct effect: $b=.396, p<.01$; indirect effect: $b=-.192, p>.05$; total effect: $b=-.238, p>.05$ ). No mediation was found in the large fiorm group (EO - direct effect: $b=.402, p>.05$; indirect effect: $b=.149, p>.05$; total effect: $b$ $=.359, p>.05$; RMO - direct effect: $b=.501, p<.05$; indirect effect: $b=-.422, p>.05$; total effect: $b=-.211, p>.05$ ). The mediation effects remained constant applying a bootstrapping approach (Zhao, Lynch, and Chen 2010).

$$
+++ \text { INSERT TABLE } 5 \text { ABOUT HERE +++ }
$$

\section{Moderators Affecting the Relationship between Social Network Usage and Firm Growth}

In order to shed additional light on the link between social network usage and firm growth, we tested the respective relationships in SMEs and large enterprise models for moderating effects. However, since multiples of the moderators are dichotomous, further application of the two-group 
SEM with those moderators would further split the sample size and result in insufficient power. This is why we switched to a regression approach of z-standardized factor scores on each single factor of EO, RMO, social network usage and firm growth. Table 6 summarizes significant moderators.

Firms that measure their social network usage's effectiveness showed differences compared to firms that do not use monitoring tools. On the one hand, SMEs could improve their effect of EO on social network usage by measuring its effectiveness (measuring: $b=.229, p<.05$; no measuring $=.074, p>.05)$. On the other hand, large firms that measured their social networking efforts showed a significantly higher effect of social network usage on firm growth $(b=.660, p<.05)$ than large firms that did not measure their efforts $(b=.156, p>.05)$. Further, not measuring social networking efforts allowed a significant effect of RMO on firm growth for SMEs $(b=.353, p$ $<.001)$ as well as for large firms $(b=.492, p<.05)$. Other differences remained insignificant. These findings draw the overall conclusion that measuring social networking efforts improves the impact of EO on social network usage for SMEs, but dilutes the impact of RMO on firm growth.

Operating in service vs. manufacturing industries also helps to differentiate SMEs' and large firms' antecedents and consequences of social network usage. In predicting social network usage, EO is significantly important for service $(b=.343, p<.001)$, but not for manufacturing SMEs, while the effect of RMO on social network usage is inversed for SMEs (service: $b=-.151$, $p<.05$; manufacturing: $b=.190, p>.05$ ). The effect of EO on firm growth is only significant for service industry SMEs $(b=.246, p<.001)$, not for manufacturing SMEs or large enterprises. Furthermore, the relationship between RMO and firm growth is more important for manufacturing $(b=.508, p<.001)$ than for service SMEs $(b=.152, p<.05)$. In contrast, social network usage is only important for large firm growth in manufacturing industries $(b=.554, p<.05)$. Again, no other systematic differences were found. With respect to SMEs, it appears that EO is advantageous in service industries, both with regard to social network usage and firm growth, while RMO is disadvantageous for social network usage. In turn, for manufacturing SMEs RMO unfolds a stronger growth effect.

Finally, customer type differentiation in terms of B2B vs. B2C contexts showed some differences. While SMEs share a comparable pattern for firm growth predictors in both segments, large enterprises are significantly different in the effects of $\mathrm{EO}(\mathrm{B} 2 \mathrm{~B}: b=.411, p<.05$; $\mathrm{B} 2 \mathrm{C}: b$ 
$=.087, p>.05)$ and social network usage on firm growth (B2B: $b=.316, p<.05$; B2C: $b=406$, $p>.05)$. For SMEs, only the relationship between EO and social network usage is higher for $\mathrm{B} 2 \mathrm{~B}$ $(b=.345, p<.001)$ than for $\mathrm{B} 2 \mathrm{C}$ contexts $(b=.238, p<.05)$. No further differences were present. EO has an evidently larger effect on SMEs' social network usage in B2B than in B2C environments.

$$
\text { +++ INSERT TABLE } 6 \text { ABOUT HERE +++ }
$$

\section{Differences in SMEs' Social Network Usage}

The linear regressions have detailed the impact of the respective variables on usage and firm growth. In order to provide a further fine-grained picture of social network technology usage in SMEs, we recoded frequency and usage patterns to a binary outcome of having implemented social networking technologies or not $(1,0)$. Thus, we switched to a binary logit regression (applying a GLM in $\mathrm{R}$ with a binary link function).

In order to take account of SMEs resource constraints, we added a measure of resource leveraging to the analysis, i.e. "doing more with less" in terms of resources available to SMEs (Morris, Schindehutte, and LaForge 2002, p.7), being measured via four items: "In our business we use relationships to friends, business partners, etc. to gain cheap access to information and advice.", "In our business we consistently try something new to be able to operate particularly economically." "We arrange with other enterprises for recommending each other to save marketing costs.", "We use relationships to other enterprises to be able to offer a wider product range more cheaply." All four items do not represent one single dimension, but form a multi-faceted, but still common factor of resource leveraging. Consequently, an omega model (Zinbarg, Yovel, Revelle, and McDonald 2006) is more appropriate and the four items represented a general factor quite well (total omega coefficient $=.79$ with all items loading significantly on that general factor). The respective facets can be described as "thrift" (items 1 and 2), "marketing effectiveness" (item 3) and "product portfolio effectiveness" (item 4). A composite score using the general factor loadings as weights to represent resource leveraging was applied. Finally, we introduced a log-transformed variable of the actual number of employees to control for firm size effects and differentiated between family and non-family firms in addition to the aforementioned moderating variables. 
A first binary model showed important differences in social network usage for SMEs. SMEs are more likely to use social networks, if they are not family-owned $(\beta=-.633, p<.05$, Odds Ratio $[\mathrm{OR}]=.531)$, service industry-embedded $(\beta=.620, \mathrm{p}<.05, \mathrm{OR}=1.859)$, and strong at leveraging resources $(\beta=.146, \mathrm{p}<.05, \mathrm{OR}=1.158)$. Moreover, we explored the types of social networks that SMEs use. To do so, we recoded social networks in B2C-focused social networks (Facebook, Google+, MySpace, and Twitter) and B2B-focused social networks (XING and LinkedIn). SMEs are more likely to use B2B social networks, if their primary clients are business customers $(\mathrm{B} 2 \mathrm{~B}$, $\beta=.903, \mathrm{p}<.001, \mathrm{OR}=2.466)$ and if they are strong at resource leveraging $(\beta=.240, \mathrm{p}<.01, \mathrm{OR}$ $=1.271)$. In contrast, B2C-focused social network technology usage is more likely for non-family SMEs $(\beta=-.640, \mathrm{p}<.05, \mathrm{OR}=.527)$ and SMEs focusing on $\mathrm{B} 2 \mathrm{C}$ environments $(\beta=-.551, \mathrm{p}<.05$, $\mathrm{OR}=.576$ ). The SME's number of employees had no effect in any of these models.

\section{Discussion}

\section{Contributions to Theory}

This study investigated the antecedents and performance-related consequences of information technology usage - more specifically the use of social networks - in SMEs. Our results confirm the hypothesized impact of EO on both social network usage and firm growth in SMEs. At the same time, RMO has the presumed positive influence on firm growth in SMEs, but, in contrast to our hypothesis, it does not impact social network usage in SMEs. Moreover, social network usage does not directly affect SME growth. Rather, the relationship between EO and SME growth is mediated by social network usage. It is interesting that this mediation effect carries through against the positive direct effect of EO on firm growth and the non-effect of social network usage on firm growth. As a result, we see that social network usage as a managerial resource needs to be combined with entrepreneurial resources in the form of EO in order to unlock its growth potential. In other words, only when an SME possesses a strong EO so that social networks are used in a proactive, innovative, and risk-oriented way can social networking technology use lead to firm growth in SMEs. On the other hand, if the SME possesses a moderate or even weak EO, the usage of social network technology itself does not drive firm performance. 
Interestingly, all results regarding social network usage differ significantly between SMEs and large firms. Among large firms, RMO positively influences social network usage, whereas EO does not. We here also see an unmediated and therefore direct positive effect of social network usage on firm growth. These findings underscore that social network marketing indeed is effective in different ways for SMEs and large firms.

In this regard, our results suggest that research on antecedents and consequences of social network usage needs to take into account firm-specific contingencies. When it comes to firm size, we see that measuring social network effectiveness improves the impact of EO on social network usage for SMEs. At the same time, it improves the effect of social network usage on large firm growth, while diluting the impact of RMO on firm growth for both SMEs and large firms at the same time. Moreover, industry seems to be a core contingency in the context of social network usage. It appears that service industry accounts for the positive effects between SMEs' EO and firm growth as well as between EO and social network usage. In turn, service SMEs with a strong RMO are less likely to use social networks. With regard to the manufacturing industry, only large firms appear to capitalize on social network technology use in terms of firm growth. For large firms, a B2B focus also creates a positive effect between social network usage and firm growth. In turn, a service focus in combination with smaller firm size brings the firm closer to its customers. This in turn might enable entrepreneurially oriented service SMEs to effectively use social networks as an information technology. At the same time, however, an SME's RMO is generally not associated with social network usage and even unfolds a negative effect among service SMEs. A possible explanation for this is that SMEs characterized by strong RMO give preference to personal customer contact (vs. impersonal contact via social networks). These kinds of SMEs would omit social networks to maintain long-term (offline) relationships.

According to Andzulis, Panagopoulos and Rapp (2012) and Kaplan and Haenlein (2012), social networking success strongly depends on regular message updates. Our descriptive results indicate that large companies tend to use social network sites more frequently and are more active on social media platforms than SMEs. A reason for these differences can be seen in perceptual differences regarding the conditions of social network usage. Whereas $25.7 \%$ of SMEs that do not employ social networking tools agree with the statement that social network usage requires a large investment in terms of time, is this only the case for $9.7 \%$ of large firms $(t=2.95, p<.01)$. So there is a significant difference between SMEs and large firms when it comes to the belief that 
social network usage results in time well spent, or, as Nakara, Benmoussa, and Jaouen (2012, p. 401) put it, "many SMEs do not make the most of these channels." This is in line with our findings regarding differences in social network usage in SMEs. SMEs are more likely to use social networks for marketing purposes the better the match between the specific social network employed (private or business networks) and its target customers (B2C vs. B2B). The finding that resource leveraging also explains SME's technology usage can be seen as a further indication that entrepreneurial resources are critical for developing managerial resources in SMEs. Upon first glance, it can therefore be assumed that the missing link between social network usage and firm growth in SMEs is caused by a lack of time, knowledge, and financial resources.

At the same time, we found an indirect performance effect of social network usage as a mediator between EO and firm growth in SMEs. Thus, the missing direct link between social network usage and firm growth in SMEs could be explained by SMEs' lack of entrepreneurial resources. If entrepreneurial resources are lacking, the firm fails to recognize new and innovative opportunities for using social networks in a way that contributes to firm growth. Only if the SME embraces innovativeness, proactiveness, and risk-taking, social media technology use can lead to firm growth. On the other side, we see a direct positive effect of social network usage on growth among large firms. This effect is particularly caused by manufacturing firms in B2B industries. Although a positive effect of social network usage on firm performance in B2B settings was also found by other authors (Järvinen, Tollinen, Karjaluoto, and Jayawardhena 2012; Powell, Groves, and Dimos 2011), we believe that this finding warrants more research. The same applies to our result that measuring social networking efforts appears to dilute the effect of RMO in both the SME and large firm context.

\section{Contributions to Managerial Practice}

In terms of practical recommendations, we propose that SMEs strengthen their entrepreneurial resources for example by empowering their employees to develop social networking campaigns that are unique, relevant, and up-to-date (Geho, Smith, and Lewis 2010; Lacho, and Marinello 2010; Pentina, and Koh 2012). Contemporary social media management solutions such as Hootsuite(.com) or Klout(.com) can be of assistance in achieving this. Furthermore, among SMEs we see that EO has a positive impact on social media technology use, whereas RMO has no or even a 
negative effect when it comes to service industries. This means that SMEs that are mainly customer-focused and want to use social networks should try to become more entrepreneurially oriented. This is of course easier said than done. However, efforts such as participative decisionmaking, a reduction of organizational hierarchies, and the permission to use work time to develop creative projects have proven to increase employee creativity (Oldham, and Cummings 1996; Zhang, and Bartol 2010). Finally, in both the public and media there is often a preconceived notion that social network marketing is primarily used for B2C marketing purposes (Shih 2009). Nevertheless, our study shows that social networking is used by B2B and B2C firms alike. Further, B2B firms seem to account for the positive effect between social network usage and growth in large firms. Thus, B2B firms should reconsider their excuses for not using social media technology for their marketing purposes (see also Järvinen, Tollinen, Karjaluoto, and Jayawardhena 2012).

\section{Contributions to Policy}

By looking closer at firms that do not employ social networking tools, we see that SMEs are more uncertain about how the implementation of social media technology can help their firm. Whereas $18.6 \%$ of SMEs that do not employ social networking sites are unsure whether and how social network usage can help their company, is this only the case in $4.2 \%$ of large firms $(t=3.05, p$ $<.01)$. Among those firms that employ social network technologies, we see that SMEs significantly agree more with the statement that social networks are unclear and not understandable $(t=2.05, p$ $<.05)$. Furthermore, there is a significant difference between SMEs and large companies when it comes to the measurement of social networking efforts. Whereas $31.6 \%$ of SMEs monitor the outcomes of their social networking campaigns, is this the case in $53.4 \%$ of large firms $(t=3.07, p$ $<.01$ ), with monitoring, however, improving the impact of EO on social network usage for SMEs.

The main implication of these findings is that if the aim of policy-makers is to support economic growth and competitiveness via entrepreneurially oriented SMEs, enhancing their usage of social network technology, for example, through easy-to-grasp user manuals and workshops would seem appropriate. This is in line with previous research that showed that a lack of training and management/technical support inhibits technology usage (Buehrer, Senecal, and Bolman Pullins 2005; Del Aguila-Obra, and Padilla-Melendez 2006). Also, our findings highlight how different firm characteristics create different barriers that prevent them from using social networks as 
marketing tool. Subsequently, understanding how internal barriers affect opportunity exploitation in the form of social network usage can assist policy makers in tailoring advice to help SMEs.

\section{Limitations}

As with any empirical investigation, our study is of course not without limitations. First of all, it was conducted in (German-speaking) Western European countries. This issue could limit the ability to transfer our results to other parts of the world. Second, given very strict data privacy laws in the countries analyzed, the online questionnaire was sent out only once without any reminders. It is therefore possible that the results are biased towards more internet- and social media-savvy respondents. However, since the descriptive results are consistent with other studies (Keel, and Bernet 2013), we expect this effect to remain limited. Third, the number of returned questionnaires from SMEs was higher than the number of questionnaires returned from large companies. This actually reflects the real structure of the economy, even though a higher rate of returned questionnaires from large companies could have in fact enhanced the data quality. Fourth, to reduce complexity and enlarge the generalizability of the results, the study treats SMEs and large firms as homogenous groups, so that statements regarding companies of particular sizes from different industries are limited. Fifth, our study offers avenues for firm growth of SMEs, using this as its dependent variable. Although (quantitative) growth being widely considered as the most important performance indicator, this view of course does not consider those firms that do not wish to grow - or grow rather "qualitatively". Sixth, social network usage was measured through the number of social networks used and the frequency of usage. Therefore, it is a quantitative indicator and can of course not measure the quality of posts on social networks. Finally, a benefit of social media in their wider sense is the "passive" use of these - namely the collection of social media customer voices as a basis for marketing decisions. To foster customer relationship management as well as to enable product improvement, RMO approaches such as the systematic monitoring of social media in combination with the use of advanced analytics are recommended (Kaplan, and Haenlein 2010). Given that we purposely tailored the study to the usage of social networking sites only, we might have missed out on these effects.

\section{Conclusion}


This study offered insights into social network usage as a special form of information technology, its outcomes, and antecedents in SMEs. Whereas only a few studies have investigated the impact of an SME's social network usage on marketing-related outcomes, this study is the first to directly link social networking with SME growth. This study is also the first large-scale empirical investigation to analyze EO and RMO in the context of social network usage in SMEs. By comparing the results to large firms we pointed out differences in social network usage that can be attributed to firm size.

This study predominantly contributes to the growing academic literature on marketing and information technology usage in SMEs, social media marketing, as well as strategic orientations. In addition, our study provides a first indication that social network usage has - with EO as an antecedent - consequences for SME growth and therefore that such concepts should be included in theories of small firm performance. By conceptualizing EO as an entrepreneurial resource and social network usage as a managerial resource, we also contribute to the discussion on the effectiveness of exploration and exploitation in SMEs, confirming that ambidexterity is required to unlock social networking sites' growth potential (He, and Wong 2004). In this regard, prior research shows that information technology usage does not only create firm growth, but that growth itself demands information technology usage (Nguyen, Newby, and Macaulay 2015; Bruque and Moyano 2007).

This paper has also created new research questions that should be addressed in the future. Here, 1) the impact of RMO on social network usage, 2) the impact of customer type and industry on the link between social network usage and firm growth, 3) resource availability as an antecedent of social network usage, and 4) the interplay between technology usage and firm growth show themselves to be of particular interest.

\section{References}

Alpkan, L., Yilmaz, C. and Kaya, N. (2007). "Market Orientation and Planning Flexibility in Smes Performance Implications and an Empirical Investigation," International Small Business Journal 25(2), 152-172.

Anderson, B.S. and Eshima, Y. (2013). "The Influence of Firm Age and Intangible Resources on the Relationship between Entrepreneurial Orientation and Firm Growth among Japanese Smes," Journal of Business Venturing 28(3), 413-429.

Andzulis, J.M., Panagopoulos, N.G. and Rapp, A. (2012). "A Review of Social Media and Implications for the Sales Process," Journal of Personal Selling and Sales Management 32(3), 305-316.

Aquino, J. (2012). "Find the Right Social Media Monitoring Tool," CRM Magazine 16(6), 33-37. 
Aral, S., Dellarocas, C. and Godes, D. (2013). "Social Media and Business Transformation: A Framework for Research," Information Systems Research 24(1), 3-13.

Arman, S.M. (2014). "Integrated Model of Social Media and Customer Relationship Management: A Literature Review," International Journal of Information, Business and Management 6(3), 118-131. Arnone, L., Colot, O., Croquet, M., Geerts, A. and Pozniak, L. (2010). "Company Managed Virtual Communities in Global Brand Strategy," Global Journal of Business Research 4(2), 76-112.

Baker, W.E. and Sinkula, J.M. (2009). "The Complementary Effects of Market Orientation and Entrepreneurial Orientation on Profitability in Small Businesses," Journal of Small Business Management 47(4), 443-464.

Barnes, N.G., Lescault, A.M. and Holmes, G. (2015).

http://www.umassd.edu/cmr/socialmediaresearch/2015fortune500/ (10-21-2013)

Bharadwaj, P.N. and Soni, R.G. (2007). "E-Commerce Usage and Perception of E-Commerce Issues among Small Firms: Results and Implications from an Empirical Study," Journal of Small Business Management 45(4), 501-521.

Boyd, H.W., Westfal, R. and Stasch, S.F. (1977). Marketing Research-Text and Cases. Homewood, IL: Richard D. Irwin.

Braojos-Gomez, J., Benitez-Amado, J. and Javier Llorens-Montes, F. (2015). "How Do Small Firms Learn to Develop a Social Media Competence?," International Journal of Information Management 35(4), 443458.

Brislin, R.W. (1980). "Translation and Content Analysis of Oral and Written Materials," in Handbook of Cross-Cultural Psychology. Eds. H. C. Triandis and J. W. Berry. Boston: Allyn and Bacon, 389-444. Bruque, S. and Moyano, J. (2007). "Organisational Determinants of Information Technology Adoption and Implementation in Smes: The Case of Family and Cooperative Firms," Technovation 27(5), 241-253. Buehrer, R.E., Senecal, S. and Bolman Pullins, E. (2005). "Sales Force Technology Usage - Reasons, Barriers, and Support: An Exploratory Investigation," Industrial Marketing Management 34(4), 389-398. Bulearca, M. and Bulearca, S. (2010). "Twitter: A Viable Marketing Tool for Smes," Global Business and Management Research: An International Journal 2(4), 296-309.

Byrne, B.M., Shavelson, R.J. and Muthén, B. (1989). "Testing for the Equivalence of Factor Covariance and Mean Structures: The Issue of Partial Measurement Invariance," Psychological bulletin 105(3), 456466.

Caldeira, M.M. and Ward, J.M. (2002). "Understanding the Successful Adoption and Use of Is/It in Smes: An Explanation from Portuguese Manufacturing Industries," Information Systems Journal 12, 121-151. Carim, L. and Warwick, C. (2013). "Use of Social Media for Corporate Communications by ResearchFunding Organisations in the Uk," Public Relations Review 39(5), 521-525.

Carter, M. (2011). http://econsultancy.com/uk/nma-archive (10-22-2013)

Carton, R.B. and Hofer, C.W. (2006). Measuring Organizational Performance-Metrics for

Entrepreneurship and Strategic Management Research. Cheltenham: Edward Elgar.

Castronovo, C. and Huang, L. (2012). "Social Media in an Alternative Marketing Communication Model," Journal of Marketing Development and Competitiveness 6(1), 117-134.

Chen, C.-N., Tzeng, L.-C., Ou, W.-M. and Chang, K.-T. (2007). "The Relationship among Social Capital, Entrepreneurial Orientation, Organizational Resources and Entrepreneurial Performance for New

Ventures " Contemporary Management Research 3(3), 213-232.

Christodoulides, G. (2009). "Branding in the Post-Internet Era," Marketing Theory 9(1), 141-144.

Chua, A.P.H., Deans, K.R. and Parker, C.M. (2009). "Exploring the Types of Smes Which Could Use Blogs as a Marketing Tool: A Proposed Future Research Agenda," Australasian Journal of Information Systems 16(1), 117-136.

Colliander, J. and Dahlen, M. (2011). "Following the Fashionable Friend: The Power of Social MediaWeighing Publicity Effectiveness of Blogs Versus Online Magazines," Journal of Advertising Research 51(1), 313-320.

Commission, E. (2003). Sme Definition: Commission Recommendation of 06 May 2003. Brussels: EU Commission. 
Constantinides, E. and Fountain, S.J. (2008). "Web 2.0: Conceptual Foundations and Marketing Issues," Journal of Direct, Data and Digital Marketing Practice 9(3), 231-244.

Coulter, K.S. and Roggeveen, A. (2012). "'Like It or Not": Consumer Responses to Word-of-Mouth Communication in on-Line Social Networks," Management Research Review 35(9), 878-899.

Covin, J.G., Green, K.M. and Slevin, D.P. (2006). "Strategic Process Effects on the Entrepreneurial Orientation-Sales Growth Rate Relationship," Entrepreneurship: Theory \& Practice 30(1), 57-81. Covin, J.G. and Slevin, D.P. (1989). "Strategic Management of Small Firms in Hostile and Benign Environments," Strategic Management Journal 10(1), 75-87.

Covin, J.G. and Slevin, D.P. (1991). "A Conceptual Model of Entrepreneurship as Firm Behaviour," Entrepreneurship: Theory and Practice 16(1), 7-24.

Del Aguila-Obra, A.R. and Padilla-Melendez, A. (2006). "Organizational Factors Affecting Internet Technology Adoption," Internet Research 16(1), 94-110.

Derham, R., Cragg, P. and Morrish, S. (2011). http://aisel.aisnet.org/pacis2011/53)

Du, H. and Jiang, W. (2015). "Do Social Media Matter? Initial Empirical Evidence," Journal of

Information Systems 29(2), 51-70.

Dyerson, R., Spinelli, R. and Harindranath, G. (2016). "Revisiting It Readiness: An Approach for Small Firms," Industrial Management \& Data Systems 116(3), 546-563.

Eggers, F., Kraus, S., Hughes, M., Laraway, S. and Snycerski, S. (2013). "Implications of Customer and Entrepreneurial Orientations for Sme Growth," Management Decision 51(3), 524-546.

Enders, A., Hungenberg, H., Denker, H.-P. and Mauch, S. (2008). "The Long Tail of Social Networking: Revenue Models of Social Networking Sites," European Management Journal 26(3), 199-211.

Ferber, R. and Verdoorn, P.J. (1962). Research Methods in Economics \& Business. New York: Macmillan.

Fillis, I., Johansson, U. and Wagner, B. (2003). "A Conceptualisation of the Opportunities and Barriers to E - Business Development in the Smaller Firm," Journal of Small Business and Enterprise Development 10(3), 336-344.

Fischer, E. and Reuber, A.R. (2011). "Social Interaction Via New Social Media:(How) Can Interactions on Twitter Affect Effectual Thinking and Behavior?," Journal of business venturing 26(1), 1-18.

Fitzgerald, M., Kruschwitz, N., Bonnet, D. and Welch, M. (2014). "Embracing Digital Technology: A New Strategic Imperative. Findings from the 2013 Digital Transformation Global Executive Study and Research Project by Mit Sloan Management Review \& Capgemini Consulting," Research Report 2013. MIT Sloan Management Review, 1-12.

Fornell, C. and Larcker, D.F. (1981). "Evaluating Structural Equation Models with Unobservable Variables and Measurement Error," Journal of Marketing Research 18(1), 39-50.

Gandhi, M. and Muruganantham, A. (2015). "Potential Influencers Identification Using Multi-Criteria Decision Making (Mcdm) Methods," Procedia Computer Science 57, 1179-1188.

Gecti, F. and Dastan, I. (2013). "The Impact of Social Media-Focused Information \& Communication Technologies on Business Performance Via Mediating Mechanisms: An Exploratory Study on Communication and Advertising Agencies in Turkey," International Journal of Business and Management 8(7), 106-115.

Geho, P., Smith, S. and Lewis, S. (2010). "Is Twitter a Viable Commercial Use Platform for Small Businesses? An Empirical Study Targeting Two Audiences in the Small Business Community," The Entrepreneurial Executive 15, 73-85.

Gensler, S., Völckner, F., Liu-Thompkins, Y. and Wiertz, C. (2013). "Managing Brands in the Social Media Environment," Journal of Interactive Marketing 27(4), 242-256.

George, J. and Simon, P. (2011). "Connecting with Customers," Baylor Business Review 30(1), 22-25.

Gerbing, D.W. and Anderson, J.C. (1988). "An Updated Paradigm for Scale Development Incorporating Unidimensionality and Its Assessment," Journal of Marketing Research 25(2), 186-192.

Giannakis-Bompolis, C. and Boutsouki, C. (2014). "Customer Relationship Management in the Era of Social Web and Social Customer: An Investigation of Customer Engagement in the Greek Retail Banking Sector," Procedia - Social and Behavioral Sciences 148, 67-78. 
Goffee, R. and Scase, R. (1995). Corporate Realities: The Dynamics of Large and Small Organisations. London: Routledge.

Gonzalez, R. and Griffin, D. (2001). "Testing Parameters in Structural Equation Modeling: Every" One" Matters," Psychological Methods 6(3), 258-269.

Gummerus, J., Liljander, V., Weman, E. and Pihlstrom, M. (2012). "Customer Engagement in a Facebook Brand Community," Management Research Review 35(9), 857-877.

Gummesson, E., Mele, C., Polese, F., Gummesson, E. and Grönroos, C. (2012). "The Emergence of the New Service Marketing: Nordic School Perspectives," Journal of Service Management 23(4), 479-497.

Gupta, A.K., Smith, K.G. and Shalley, C.E. (2006). "The Interplay between Exploration and

Exploitation," Academy of Management Journal 49(4), 693-706.

Hakala, H. (2011). "Strategic Orientations in Management Literature: Three Approaches to Understanding the Interaction between Market, Technology, Entrepreneurial and Learning Orientations," International Journal of Management Reviews 13(2), 199-217.

Harrigan, P., Soutar, G., Choudhury, M.M. and Lowe, M. (2015). "Modelling Crm in a Social Media Age," Australasian Marketing Journal (AMJ) 23(1), 27-37.

Harris, L. and Rae, A. (2009). "Social Networks: The Future of Marketing for Small Business," Journal of Business Strategy 30(5), 24-31.

Harris, L., Rae, A. and Grewal, S. (2008). "Out on the Pull: How Small Firms Are Making Themselves Sexy with New Online Promotion Techniques," International Journal of Technology Marketing 3(2), 153168.

Hatak, I., Kautonen, T., Fink, M. and Kansikas, J. (2016). "Innovativeness and Subsequent Family-Firm Performance: The Moderating Effect of Family Commitment," Technological Forecasting and Social Change 102, 120-131.

He, Z.-L. and Wong, P.-K. (2004). "Exploration Vs. Exploitation: An Empirical Test of the Ambidexterity Hypothesis," Organization Science 15(4), 481-494.

Hennig-Thurau, T., Malthouse, E.C., Friege, C., Gensler, S., Lobschat, L., Rangaswamy, A. and Skiera, B. (2010). "The Impact of New Media on Customer Relationships," Journal of Service Research 13(3), 311330.

Hoffman, D.L. and Fodor, M. (2010). "Can You Measure the Roi of Your Social Media Marketing," MIT Sloan Management Review 52(1), 41-49.

Hoffman, D.L. and Novak, T.P. (2012). "Toward a Deeper Understanding of Social Media," Journal of Interactive Marketing 26(2), 69-70.

Hothi, H., Saleena, B. and Prakash, B. (2015). "Experiencing Company's Popularity and Finding Correlation between Companies in Various Countries Using Facebook's Insight Data," Procedia Computer Science 50, 433-439.

Hunt, S.D., Sparkman Jr, R.D. and Wilcox, J.B. (1982). "The Pretest in Survey Research: Issues and Preliminary Findings," Journal of Marketing Research 19(2), 269-273.

Hutton, G. and Fosdick, M. (2011). "The Globalization of Social Media: Consumer Relationships with Brands Evolve in the Digital Space," Journal of Advertising Research 51(4), 564-570.

Iacobucci, D., Saldanha, N. and Deng, X. (2007). "A Meditation on Mediation: Evidence That Structural Equations Models Perform Better Than Regressions," Journal of Consumer Psychology 17(2), 139-153. Ireland, R.D., Hitt, M.A. and Simon, D.G. (2003). "A Model of Strategic Entrepreneurship: The Construct and Its Dimensions," Journal of Management 29(6), 963-989.

Jang, H.-J., Sim, J., Lee, Y. and Kwon, O. (2013). "Deep Sentiment Analysis: Mining the Causality between Personality-Value-Attitude for Analyzing Business Ads in Social Media," Expert Systems with Applications 40(18), 7492-7503.

Järvinen, J., Tollinen, A., Karjaluoto, H. and Jayawardhena, C. (2012). "Digital and Social Media Marketing Usage in B2b Industrial Section," The Marketing Management Journal 22(2), 102-117. Jarvis, C.B., MacKenzie, S.B. and Podsakoff, P.M. (2003). "A Critical Review of Construct Indicators and Measurement Model Misspecification in Marketing and Consumer Research," Journal of Consumer Research 30(2), 199-218. 
Jiang, G., Tadikamalla, P.R., Shang, J. and Zhao, L. (2016). "Impacts of Knowledge on Online Brand Success: An Agent-Based Model for Online Market Share Enhancement," European Journal of Operational Research 248(3), 1093-1103.

Jiang, S., Chen, H., Nunamaker, J.F. and Zimbra, D. (2014). "Analyzing Firm-Specific Social Media and Market: A Stakeholder-Based Event Analysis Framework," Decision Support Systems 67, 30-39. Johnston, D.A., Wade, M. and McClean, R. (2007). "Does E-Business Matter to Smes? A Comparison of the Financial Impacts of Internet Business Solutions on European and North American Smes," Journal of Small Business Management 45(3), 354-361.

Jussila, J.J., Kärkkäinen, H. and Aramo-Immonen, H. (2014). "Social Media Utilization in Business-toBusiness Relationships of Technology Industry Firms," Computers in Human Behavior 30, 606-613.

Kannabiran, G. and Dharmalingam, P. (2012). "Enablers and Inhibitors of Advanced Information Technologies Adoption by Smes," Journal of Enterprise Information Management 25(2), 186-209. Kaplan, A.M. and Haenlein, M. (2010). "Users of the World, Unite! The Challenges and Opportunities of Social Media," Business Horizons 53(1), 59-68.

--- (2012). "The Britney Spears Universe: Social Media and Viral Marketing at Its Best," Business Horizons 55(1), 27-31.

Keel, G. and Bernet, M. (2013). Social Media Wird Alltag: Integration Nimmt Zu: Bernet Zhaw Studie Social Media Schweiz 2013. Zürich, CH: Bernet PR AG \& Züricher Hochschule für Angewandte Wissenschaften.

Keith, T. (2006). Multiple Regression and Beyond: Pearson Education Boston, MA.

Kesting, P. and Günzel-Jensen, F. (2015). "Smes and New Ventures Need Business Model Sophistication," Business Horizons 58(3), 285-293.

Kietzmann, J.H., Hermkens, K., McCarthy, I.P. and Silvestre, B.S. (2011). "Social Media? Get Serious! Understanding the Functional Building Blocks of Social Media," Business Horizons 54(3), 241-251.

Kim, W.G., Lim, H. and Brymer, R.A. (2015). "The Effectiveness of Managing Social Media on Hotel Performance," International Journal of Hospitality Management 44, 165-171.

Kirchgeorg, M., Ermer, B., Brühe, C. and Hartmann, D. (2009). Live Trends 2009/10: Live@VirtuellNeue Formen Des Kundendialogs. Köln: Uniplan GmbH \& Co. KG.

Kohli, A.K., Jaworski, B.J. and Kumar, A. (1993). "Markor - a Measure of Market Orientation," Journal of Marketing Research 30(4), 467-477.

Kraus, S., Rigtering, J.C., Hughes, M. and Hosman, V. (2012). "Entrepreneurial Orientation and the Business Performance of Smes: A Quantitative Study from the Netherlands," Review of Managerial Science 6(2), 161-182.

Kudeshia, C., Sikdar, P. and Mittal, A. (2016). "Spreading Love through Fan Page Liking: A Perspective on Small Scale Entrepreneurs," Computers in Human Behavior 54, 257-270.

Lacho, K.J. and Marinello, C. (2010). "How Small Business Owners Can Use Social Networking to Promote Their Business," The Entrepreneurial Executive 15, 127-133.

Lau, R.Y.K., Li, C. and Liao, S.S.Y. (2014). "Social Analytics: Learning Fuzzy Product Ontologies for Aspect-Oriented Sentiment Analysis," Decision Support Systems 65, 80-94.

Lechner, C., Dowling, M. and Welpe, I. (2006). "Firm Networks and Firm Development: The Role of the Relational Mix," Journal of Business Venturing 21(4), 514-540.

Lee, J. and Runge, J. (2001). "Adoption of Information Technology in Small Business: Testing Drivers of Adoption for Entrepreneurs," The Journal of Computer Information Systems 42(1), 44-57.

Lee, S. and Cho, M. (2011). "Social Media Use in a Mobile Broadband Environment: Examination of Determinants of Twitter and Facebook Use," International Journal of Mobile Marketing 6(2), 71-87. Lipsman, A., Mudd, G., Rich, M. and Bruich, S. (2012). "The Power of" Like": How Brands Reach (and Influence) Fans through Social-Media Marketing," Journal of Advertising Research 52(1), 40.

Livingstone, S. (2008). "Taking Risky Opportunities in Youthful Content Creation: Teenagers' Use of Social Networking Sites for Intimacy, Privacy and Self-Expression," New media \& society 10(3), 393411. 
Lumpkin, G.T. and Dess, G.G. (1996). "Clarifying the Entrepreneurial Orientation Construct and Linking It to Performance," Academy of Management Review 21(1), 135-172.

Lyon, D.W., Lumpkin, G.T. and Dess, G.G. (2000). "Enhancing Entrepreneurial Orientation Research: Operationalizing and Measuring a Key Strategic Decision Making Process," Journal of Management 26(5), 1055-1085.

Macpherson, A. and Holt, R. (2007). "Knowledge, Learning and Small Firm Growth: A Systematic Review of the Evidence," Research Policy 36(2), 172-192.

Malaquias, R.F. and Hwang, Y. (2015). "Firms' Size and Use of Information and Communication Technologies: Empirical Evidence on Small Businesses in Brazil," Information Development.

Malthouse, E.C., Haenlein, M., Skiera, B., Wege, E. and Zhang, M. (2013). "Managing Customer Relationships in the Social Media Era: Introducing the Social Crm House," Journal of Interactive Marketing 27(4), 270-280.

Mangold, W.G. and Faulds, D.J. (2009). "Social Media: The New Hybrid Element of the Promotion Mix," Business Horizons 52(4), 357-365.

March, J.G. (1991). "Exploration and Exploitation in Organizational Learning," Organization Science 2(1), 71-87.

Martínez-Núñez, M. and Pérez-Aguiar, W.S. (2014). "Efficiency Analysis of Information Technology and Online Social Networks Management: An Integrated Dea-Model Assessment," Information \& Management 51(6), 712-725.

Maruyama, G. (1997). Basics of Structural Equation Modeling. Thousand Oaks, CA: Sage.

Michaelidou, N., Siamagka, N.T. and Christodoulides, G. (2011). "Usage, Barriers and Measurement of Social Media Marketing: An Exploratory Investigation of Small and Medium B2b Brands," Industrial Marketing Management 40(7), 1153-1159.

Miller, D. (1983). "The Correlates of Entrepreneurship in 3 Types of Firms," Management Science 29(7), 770-791.

Mitchell, W. and Singh, K. (1993). "Death of the Lethargic: Effects of Expansion into New Technical Subfields on Performance in a Firm's Base Business," Organization Science 4(2), 152-180.

Moran, G. (2009). http://www.entrepreneur.com/article/204380\# (10-22-2013)

Morris, M.H., Schindehutte, M. and LaForge, R.W. (2002). "Entrepreneurial Marketing: A Construct for Integrating Emerging Entrepreneurship and Marketing Perspectives," Journal of Marketing Theory \& Practice 10(4), 1-19.

Nakara, W.A., Benmoussa, F.Ä. and Jaouen, A. (2012). "Entrepreneurship and Social Media Marketing: Evidence from French Small Business," International Journal of Entrepreneurship and Small Business 16(4), 386-405.

Narver, J.C. and Slater, S.F. (1990). "The Effect of a Market Orientation on Business Profitability," Journal of Marketing 54(4), 20-35.

Narver, J.C., Slater, S.F. and MacLachlan, D.L. (2004). "Responsive and Proactive Market Orientation and New-Product Success," Journal of Product Innovation Management 21(5), 334-347.

Nguyen, T.H. (2009). "Information Technology Adoption in Smes: An Integrated Framework," International Journal of Entrepreneurial Behavior \& Research 15(2), 162-186.

Nguyen, T.H., Newby, M. and Macaulay, M.J. (2015). "Information Technology Adoption in Small Business: Confirmation of a Proposed Framework," Journal of Small Business Management 53(1), 207227.

Nickell, D., Rollins, M. and Hellman, K. (2013). "How to Not Only Survive but Thrive During Recession: A Multi - Wave, Discovery - Oriented Study," Journal of Business \& Industrial Marketing 28(5), 455461.

Oldham, G.R. and Cummings, A. (1996). "Employee Creativity: Personal and Contextual Factors at Work," Academy of Management Journal 39(3), 607-634.

Öztamur, D. and Karakadılar, İ.S. (2014). "Exploring the Role of Social Media for Smes: As a New Marketing Strategy Tool for the Firm Performance Perspective," Procedia - Social and Behavioral Sciences 150, 511-520. 
Paniagua, J. and Sapena, J. (2014). "Business Performance and Social Media: Love or Hate?," Business Horizons 57(6), 719-728.

Pelham, A.M. (2000). "Market Orientation and Other Potential Influences on Performance in Small and Medium-Sized Manufacturing Firms," Journal of Small Business Management 38(1), 48-67.

Peltier, J.W., Schibrowsky, J.A. and Zhao, Y. (2009). "Understanding the Antecedents to the Adoption of Crm Technology by Small Retailers," International Small Business Journal 27(3), 307-336.

Pentina, I. and Koh, A.C. (2012). "Exploring Social Media Marketing Strategies in Smes," International Journal of Internet Marketing and Advertising 7(4), 292-310.

Petter, S., DeLone, W. and McLean, E. (2008). "Measuring Information Systems Success: Models, Dimensions, Measures, and Interrelationships," European journal of information systems 17(3), 236-263.

Powell, G., Groves, S. and Dimos, J. (2011). Roi of Social Media: How to Improve the Return on Your Social Marketing Investment. Singapore: Wiley.

Pöyry, E., Parvinen, P. and Malmivaara, T. (2013). "Can We Get from Liking to Buying? Behavioral Differences in Hedonic and Utilitarian Facebook Usage," Electronic Commerce Research and Applications 12(4), 224-235.

Premkumar, G. (2003). "A Meta-Analysis of Research on Information Technology Implementation in Small Business," Journal of Organizational Computing and Electronic Commerce 13(2), 91-121. Qu, Z., Wang, Y., Wang, S. and Zhang, Y. (2013). "Implications of Online Social Activities for E Tailers' Business Performance," European Journal of Marketing 47(8), 1190-1212.

Rapp, A., Beitelspacher, L.S., Grewal, D. and Hughes, D.E. (2013). "Understanding Social Media Effects across Seller, Retailer, and Consumer Interactions," Journal of the Academy of Marketing Science 41(5), 547-566.

Rauch, A., Wiklund, J., Lumpkin, G.T. and Frese, M. (2009). "Entrepreneurial Orientation and Business Performance: An Assessment of Past Research and Suggestions for the Future," Entrepreneurship Theory and Practice 33(3), 761-787.

Riemenschneider, C.K., Harrison, D.A. and Mykytyn, P.P. (2003). "Understanding It Adoption Decisions in Small Business: Integrating Current Theories," Information \& Management 40(4), 269-285.

Rigtering, J.C., Kraus, S., Eggers, F. and Jensen, S.H. (2013). "A Comparative Analysis of the

Entrepreneurial Orientation/Growth Relationship in Service Firms and Manufacturing Firms," The Service Industries Journal(ahead-of-print), 1-20.

Rodriguez, M., L. Dixon, A. and W. Peltier, J. (2014). "A Review of the Interactive Marketing Literature in the Context of Personal Selling and Sales Management," Journal of Research in Interactive Marketing 8(4), 294-308.

Sabherwal, R., Jeyaraj, A. and Chowa, C. (2006). "Information System Success: Individual and Organizational Determinants," Management science 52(12), 1849-1864.

Schmidt, S.M. and Ralph, D.L. (2011). "Social Media: More Available Marketing Tools," Business Review 18(2), 37-43.

Schniederjans, D., Cao, E.S. and Schniederjans, M. (2013). "Enhancing Financial Performance with Social Media: An Impression Management Perspective," Decision Support Systems 55(4), 911-918. Schultz, R.J., Schwepker, C.H. and Good, D.J. (2012). "Social Media Usage: An Investigation of B2b Salespeople," American Journal of Business 27(2), 174-194.

Scott, D.M. (2009). The New Rules of Marketing and Pr: How to Use Social Media, Blogs, News

Releases, Online Video, and Viral Marketing to Reach Buyers Directly. Hoboken, NJ: John Wiley \& Sons. Seo, D. and Lee, J. (2016). "Web 2.0 and Five Years Since: How the Combination of Technological and Organizational Initiatives Influences an Organization's Long-Term Web_2.0 Performance," Telematics and Informatics 33(1), 232-246.

Shih, C. (2009). The Facebook Era: Tapping Online Social Networks to Build Better Products, Reach New Audiences, and Sell More Stuff. Boston: Prentice Hall.

Slater, S.F. and Narver, J.C. (1998). "Customer-Led and Market-Oriented - Let's Not Confuse the Two," Strategic Management Journal 19(10), 1001-1006. 
Sledgianowski, D. and Kulviwat, S. (2009). "Using Social Network Sites: The Effects of Playfulness, Critical Mass and Trust in a Hedonic Context," Journal of Computer Information Systems 49(4), 74-83. Solomon, G. and Perry, V.G. (2011). "Looking out for the Little Guy: The Effects of Technical Assistance on Small Business Financial Performance," Journal of Marketing Development and Competitiveness 5(4), 21-31.

Solomon, G.T., Bryant, A., May, K. and Perry, V. (2013). "Survival of the Fittest: Technical Assistance, Survival and Growth of Small Businesses and Implications for Public Policy," Technovation 33(8-9), 292301.

Steinman, M.L. and Hawkins, M. (2010). "When Marketing through Social Media, Legal Risks Can Go Viral," Intellectual Property \& Technology Law Journal 22(8), 1-9.

Stockdale, R., Ahmed, A. and Scheepers, H. (2012). http://aisel.aisnet.org/pacis2012/169/)

Sun, M., Chen, Z.-Y. and Fan, Z.-P. (2014). "A Multi-Task Multi-Kernel Transfer Learning Method for Customer Response Modeling in Social Media," Procedia Computer Science 31, 221-230.

Thong, J.Y.L. (1999). "An Integrated Model of Information Systems Adoption in Small Businesses," Journal of Management Information Systems 15(4), 187-214.

--- (2001). "Resource Constraints and Information Systems Implementation in Singaporean Small

Businesses," Omega 29, 143-156.

Thoumrungroje, A. (2014). "The Influence of Social Media Intensity and Ewom on Conspicuous

Consumption," Procedia - Social and Behavioral Sciences 148, 7-15.

Tocher, N. and Rutherford, M.W. (2009). "Perceived Acute Human Resource Management Problems in

Small and Medium Firms: An Empirical Examination," Entrepreneurship Theory and Practice 33(2), 455479 .

Tomaras, P. and Ntalianis, K. (2015). "Evaluating the Impact of Posted Advertisements on Content Sharing Sites: An Unsupervised Social Computing Approach," Procedia - Social and Behavioral Sciences 175, 219-226.

Trainor, K.J., Andzulis, J., Rapp, A. and Agnihotri, R. (2014). "Social Media Technology Usage and Customer Relationship Performance: A Capabilities-Based Examination of Social Crm," Journal of Business Research 67(6), 1201-1208.

Trusov, M., Bucklin, R.E. and Pauwels, K.H. (2009). "Effects of Word-of-Mouth Versus Traditional Marketing: Findings from an Internet Social Networking Site," Journal of Marketing 75(5), 90-102. Vargo, S.L. and Lusch, R.F. (2004). "Evolving to a New Dominant Logic for Marketing," Journal of Marketing 68(1), 1-17.

Vernuccio, M. (2014). "Communicating Corporate Brands through Social Media an Exploratory Study," International Journal of Business Communication 51(3), 211-233.

Weinberg, B.D. and Pehlivan, E. (2011). "Social Spending: Managing the Social Media Mix," Business Horizons 54(3), 275-282.

Wickert, A. and Herschel, R. (2001). "Knowledge-Management Issues for Smaller Businesses," Journal of Knowledge management 5(4), 329-337.

Wiklund, J. and Shepherd, D. (2003). "Aspiring for, and Achieving Growth: The Moderating Role of Resources and Opportunities*," Journal of management studies 40(8), 1919-1941.

Wiklund, J. and Shepherd, D.A. (2011). "Where to from Here? Eo - as - Experimentation, Failure, and Distribution of Outcomes," Entrepreneurship Theory and Practice 35(5), 925-946.

Williamson, I.O., Cable, D.M. and Aldrich, H.E. (2002). "Smaller but Not Necessarily Weaker: How Small Businesses Can Overcome Barriers to Recruitment," in Advances in Entrepreneurship, Firm Emergence and Firm Growth. Eds. J. A. Katz and T. M. Welbourne. Greenwich, CT: JAI Press, 83-106. Wu, Y.-C.J., Lirn, T.-c. and Dong, T.-P. (2014). "What Can We Learn from Advertisements of Logistics Firms on Youtube? A Cross Cultural Perspective," Computers in Human Behavior 30, 542-549.

Yu, Y., Duan, W. and Cao, Q. (2013). "The Impact of Social and Conventional Media on Firm Equity Value: A Sentiment Analysis Approach," Decision Support Systems 55(4), 919-926. 
Zaglia, M., Waiguny, M., Abfalter, D. and Mueller, J. (2014). "The Influence of Online Social Networks on Performance of Small and Medium Enterprises: An Empirical Investigation of the Online Business to Business Network Xing," International Journal of Entrepreneurial Venturing, in press.

Zhang, X. and Bartol, K.M. (2010). "Linking Empowering Leadership and Employee Creativity: The Influence of Psychological Empowerment, Intrinsic Motivation, and Creative Process Engagement," Academy of Management Journal 53(1), 107-128.

Zhao, X., Lynch, J.G. and Chen, Q. (2010). "Reconsidering Baron and Kenny: Myths and Truths About Mediation Analysis," Journal of Consumer Research 37(2), 197-206.

Zinbarg, R., Yovel, I., Revelle, W. and McDonald, R. (2006). "Estimating Generalizability to a Universe of Indicators That All Have One Attribute in Common: A Comparison of Estimators for Omega," Applied Psychological Measurement, 30(2), 121-144. 
Figures

Figure 1

Hypotheses

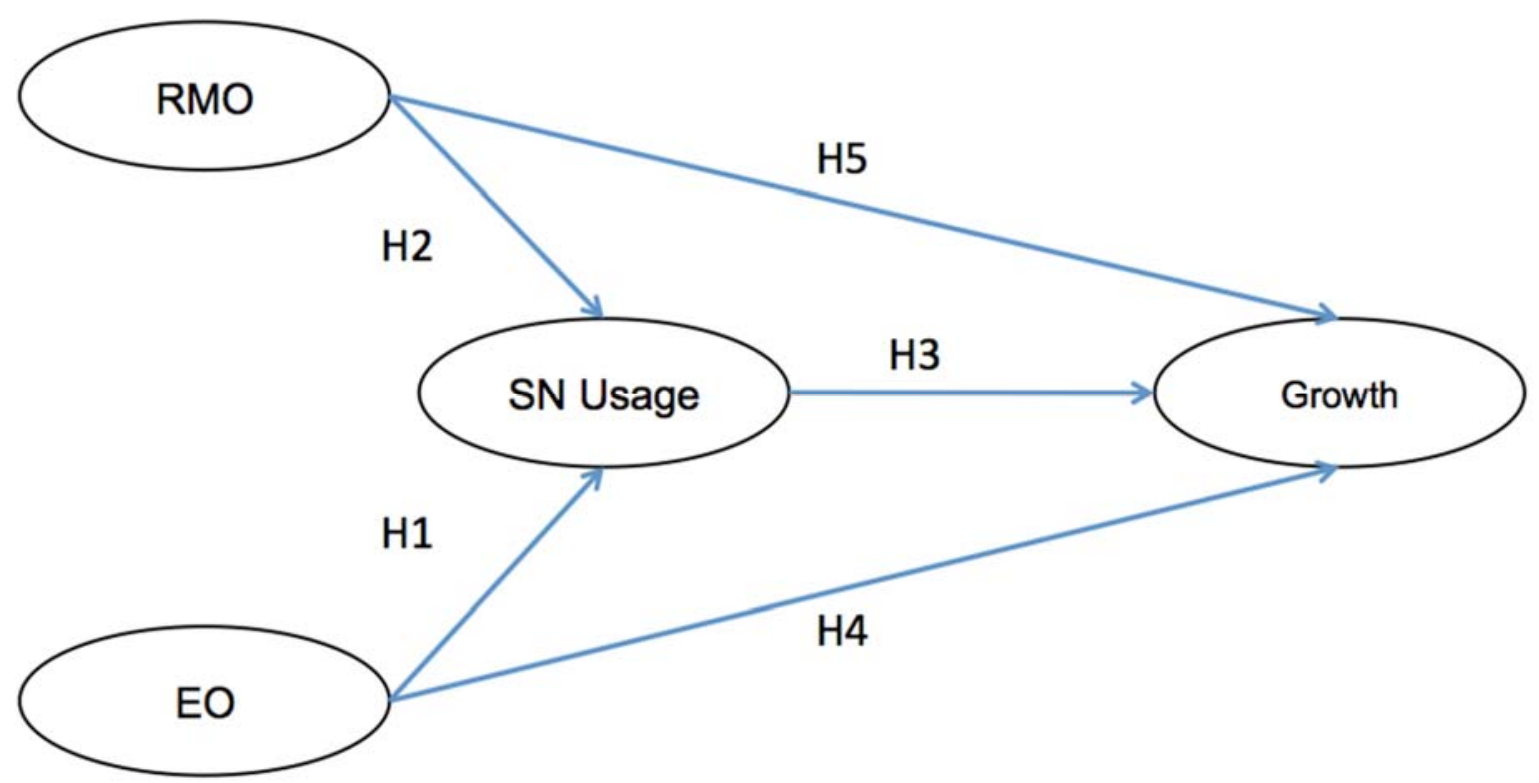




\section{Tables}

Table 1

Overview of Sample Characteristics

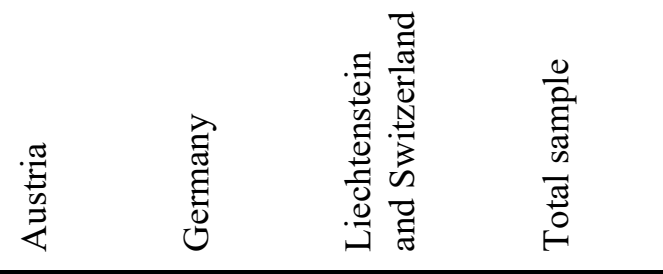

\section{Sample characteristics}

Number of returned questionnaires

$\begin{array}{llll}252 & 183 & 161 & 596 \\ 25.2 \% & 18.3 \% & 16.1 \% & 19.9 \% \\ 189 & 120 & 102 & 411 \\ 18.9 \% & 12.0 \% & 10.2 \% & 13.7 \%\end{array}$

Effective response rate

$18.9 \%$

$\begin{array}{llll}8 & 66 & 27 & 17 \\ 65.0 \% & 93.1 \% & 83.3 \% & 82.5 \% \\ 16.4 \% & 24.2 \% & 21.6 \% & 20.0 \% \\ 44.4 \% & 64.2 \% & 48.0 \% & 51.1 \% \\ 27.5 \% & 5.0 \% & 23.5 \% & 20.0 \% \\ 11.1 \% & 2.5 \% & 3.1 \% & 6.8 \% \\ 0.5 \% & 4.2 \% & 2.9 \% & 2.2 \% \\ & & & \\ 26.5 \% & 12.5 \% & 4.9 \% & 17.0 \% \\ 8.5 \% & 8.3 \% & 2.0 \% & 6.8 \% \\ 65.1 \% & 79.2 \% & 93.1 \% & 76.2 \%\end{array}$

Median firm size

Percentage SMEs

Percentage manufacturing companies

Percentage service companies

Percentage trading companies

Percentage hotel and restaurants

Percentage transportation companies

Legal form of organization

- Individual enterprises (e.g. e.K, e.Kfm)

- Business partnerships (e.g. GbR, $O G, K G$ )

- Corporate entities (e.g. GmbH, $A G$ )

$\mathrm{B} 2 \mathrm{~B} / \mathrm{B} 2 \mathrm{C}$ orientation

\begin{tabular}{lllll}
$-B 2 B$ & $65.1 \%$ & $70.8 \%$ & $74.5 \%$ & $69.1 \%$ \\
$-B 2 C$ & $34.9 \%$ & $29.2 \%$ & $25.5 \%$ & $30.9 \%$ \\
\hline
\end{tabular}


Table 2

Social Network Usage

\begin{tabular}{lrrr}
\hline \hline & SMEs (\%) & Large (\%) & N (\%) \\
\hline Yes & $196(58)$ & $58(81)$ & $254(62)$ \\
No & $115(34)$ & $9(13)$ & $124(30)$ \\
Plan to start with the use of social networks in the next 2 years & $28(8)$ & $5(7)$ & $33(8)$ \\
Total & 339 & 72 & 411 \\
\hline \hline
\end{tabular}

Table 3

Most Popular Social Networking Sites

\begin{tabular}{lrrr}
\hline \hline SNS & SMEs $(\%)$ & Large $(\%)$ & N (\%) \\
\hline Facebook & $150(44)$ & $45(63)$ & $195(47)$ \\
XING & $119(35)$ & $55(76)$ & $174(42)$ \\
Twitter & $62(18)$ & $33(46)$ & $95(23)$ \\
Google+ & $61(18)$ & $24(33)$ & $85(21)$ \\
LinkedIn & $54(16)$ & $31(43)$ & $85(21)$ \\
Total & 446 & 188 & 634 \\
\hline \hline
\end{tabular}


Table 4

Measured Variables' Factor Loadings on Latent Variables (CFA)

\begin{tabular}{|c|c|c|c|c|c|}
\hline $\begin{array}{l}\text { Latent } \\
\text { Variable }\end{array}$ & $\begin{array}{l}\text { Measured } \\
\text { Variable }\end{array}$ & $\begin{array}{l}\text { Standard- } \\
\text { ized Esti- } \\
\text { mate } \\
(\text { SMEs) }\end{array}$ & $\begin{array}{l}S E \\
(S M E S)\end{array}$ & $\begin{array}{l}\text { Standard- } \\
\text { ized } \\
\text { Estimate } \\
(L E)\end{array}$ & $\begin{array}{l}S E \\
(L E)\end{array}$ \\
\hline \multirow{2}{*}{$\begin{array}{l}\text { Social net- } \\
\text { work usage }\end{array}$} & Number of social networks used & 1.000 & --- & 1.000 & --- \\
\hline & Frequency of usage & .766 & .059 & .716 & .104 \\
\hline \multirow[t]{4}{*}{ RMO } & $\begin{array}{l}\text { Understanding of customer } \\
\text { needs }\end{array}$ & .595 & --- & .730 & --- \\
\hline & Measure customer satisfaction & .614 & 194 & .534 & .242 \\
\hline & More customer focused & .597 & .156 & .905 & .276 \\
\hline & Disseminate data & .624 & .173 & .495 & .264 \\
\hline \multirow[t]{3}{*}{ EO } & Risk & .602 & --- & .556 & --- \\
\hline & Proactiveness & .759 & .112 & .728 & .242 \\
\hline & Innovativeness & .813 & .128 & .862 & .321 \\
\hline \multirow{3}{*}{$\begin{array}{l}\text { Firm } \\
\text { growth }\end{array}$} & More sales & .921 & --- & .912 & --- \\
\hline & More profit & .877 & .047 & .919 & .079 \\
\hline & More market share & .744 & .051 & .869 & .086 \\
\hline
\end{tabular}

Table 5

Empirical SEM Results

\begin{tabular}{|c|c|c|c|c|c|c|c|c|c|c|}
\hline \multirow[t]{2}{*}{ Effects } & & & \multicolumn{3}{|c|}{ SMEs } & \multicolumn{3}{|c|}{$L E$} & \multicolumn{2}{|c|}{ Difference } \\
\hline & & & $\boldsymbol{\beta}$ & SE & $\mathbf{p}$ & $\boldsymbol{\beta}$ & SE & $\mathbf{p}$ & $\mathbf{z}$ & $\mathbf{p}$ \\
\hline H1: EO & $\rightarrow$ & Social network usage & .421 & .247 & .000 & .151 & .485 & .264 & 2.543 & .006 \\
\hline H2: RMO & $\rightarrow$ & Social network usage & -.154 & .265 & .067 & .221 & .417 & .017 & 1.809 & .036 \\
\hline $\begin{array}{l}\text { H3: Social net- } \\
\text { work usage }\end{array}$ & $\rightarrow$ & Firm growth & -.086 & .031 & .146 & .303 & .059 & .011 & 5.843 & .000 \\
\hline H4: EO & $\rightarrow$ & Firm growth & .240 & .137 & .007 & .221 & .246 & .107 & .193 & .424 \\
\hline H5: RMO & $\rightarrow$ & Firm growth & .237 & .148 & .007 & .303 & .215 & .027 & .508 & .306 \\
\hline
\end{tabular}

Note that $\beta$ : standardized path coefficient (beta), SE: standard error of beta, $\mathrm{p}$ : $\mathrm{p}$-value of beta, Difference $\mathrm{Z}$ test is one-tailed 
Table 6

Important Moderation Effects

\begin{tabular}{|c|c|c|c|c|c|c|c|c|c|}
\hline \multicolumn{3}{|c|}{ Hypothesis / Effect } & \multirow[t]{2}{*}{ Group } & \multirow[t]{2}{*}{ Moderator } & \multicolumn{3}{|c|}{ Coefficient } & \multicolumn{2}{|c|}{ Difference } \\
\hline & & & & & b & SE & $\mathbf{p}_{\mathbf{b}}$ & $\mathbf{F}$ & $\mathbf{p}_{\mathbf{F}}$ \\
\hline \multirow[t]{6}{*}{ H1: EO } & $\rightarrow$ & SN usage & SME & SN measuring & .229 & .088 & .009 & 7.859 & .000 \\
\hline & & & & No SN measuring & .074 & .060 & .221 & & \\
\hline & & & SME & Manufacturing & .196 & .125 & .117 & 15.564 & .000 \\
\hline & & & & Service & .343 & .062 & .000 & & \\
\hline & & & SME & $\mathrm{B} 2 \mathrm{~B}$ & .345 & .069 & .000 & 16.310 & .000 \\
\hline & & & & $\mathrm{B} 2 \mathrm{C}$ & .238 & .096 & .014 & & \\
\hline \multirow[t]{2}{*}{ H2: RMO } & $\rightarrow$ & SN usage & SME & Manufacturing & .190 & .132 & .151 & 3.413 & .034 \\
\hline & & & & Service & -.151 & .069 & .029 & & \\
\hline \multirow[t]{6}{*}{ H3: SN usage } & $\rightarrow$ & Firm growth & LE & SN measuring & .660 & .289 & .027 & 3.790 & .029 \\
\hline & & & & No SN measuring & .156 & .332 & .640 & & \\
\hline & & & LE & Manufacturing & .554 & .214 & .012 & 4.874 & .011 \\
\hline & & & & Service & .268 & .163 & .105 & & \\
\hline & & & LE & $\mathrm{B} 2 \mathrm{~B}$ & .316 & .138 & .026 & 3.548 & .035 \\
\hline & & & & $\mathrm{B} 2 \mathrm{C}$ & .406 & .239 & .094 & & \\
\hline \multirow[t]{6}{*}{ H4: EO } & $\rightarrow$ & Firm growth & SME & SN measuring & .565 & .166 & .000 & 11.692 & .000 \\
\hline & & & & No SN measuring & .122 & .111 & .272 & & \\
\hline & & & SME & Manufacturing & .143 & .131 & .278 & 16.233 & .000 \\
\hline & & & & Service & .246 & .068 & .000 & & \\
\hline & & & LE & $\mathrm{B} 2 \mathrm{~B}$ & .411 & .184 & .029 & 3.947 & .024 \\
\hline & & & & $\mathrm{B} 2 \mathrm{C}$ & .087 & .226 & .700 & & \\
\hline \multirow[t]{6}{*}{ H5: RMO } & $\rightarrow$ & Firm growth & SME & SN measuring & .098 & .187 & .599 & 4.942 & .008 \\
\hline & & & & No SN measuring & .353 & .110 & .000 & & \\
\hline & & & LE & SN measuring & .070 & .187 & .711 & 4.037 & .024 \\
\hline & & & & No SN measuring & .492 & .194 & .014 & & \\
\hline & & & SME & Manufacturing & .508 & .139 & .000 & 9.022 & .000 \\
\hline & & & & Service & .152 & .072 & .036 & & \\
\hline
\end{tabular}

Note that $b$ : unstandardized path coefficient, SE: standard error of $b$, $p_{b}$ : p-value of $b, F$ : F-value of difference test, p: $p_{F}$-value of $F$; $a$ difference is called significant only if one or both path coefficients and the difference test are significant. 


\section{Appendix}

\section{Table A1}

\section{Systematic Literature Review}

\begin{tabular}{|c|c|c|c|c|}
\hline Author(s) & Research question & Results & $\begin{array}{l}\text { Research } \\
\text { method }\end{array}$ & $\begin{array}{l}\text { Sam- } \\
\text { ple size }\end{array}$ \\
\hline $\begin{array}{l}\text { Seo, and Lee } \\
2016\end{array}$ & $\begin{array}{l}\text { The paper analyzes different } \\
\text { types of initiatives pursued } \\
\text { by companies to start a social } \\
\text { media presence and their im- } \\
\text { pact on an organization's } \\
\text { later use of these technolo- } \\
\text { gies from a long-term per- } \\
\text { spective. }\end{array}$ & $\begin{array}{l}\text { Concurrently preparing both techno- } \\
\text { logical and organizational initiatives } \\
\text { is important for social media success, } \\
\text { along with a correct and precise un- } \\
\text { derstanding of the firm's core value } \\
\text { proposition. The results show a mod- } \\
\text { erate level of dependence between } \\
\text { the organizations' initiatives and } \\
\text { their performance } 5 \text { years later. }\end{array}$ & qualitative & 5 \\
\hline $\begin{array}{l}\text { Kudeshia, } \\
\text { Sikdar, and } \\
\text { Mittal } 2016 \\
\end{array}$ & $\begin{array}{l}\text { The study analyzes the effec- } \\
\text { tiveness of social media as a } \\
\text { communication tool for } \\
\text { SMEs and small scale entre- } \\
\text { preneurs. }\end{array}$ & $\begin{array}{l}\text { The study reveals a positive relation- } \\
\text { ship between "liked" brands on Face- } \\
\text { book and brand love. Further, the } \\
\text { study finds that liking fan pages is } \\
\text { essentially converted into word-of- } \\
\text { mouth, which results in purchase in- } \\
\text { tentions. }\end{array}$ & $\begin{array}{l}\text { quantita- } \\
\text { tive }\end{array}$ & 311 \\
\hline $\begin{array}{l}\text { Jiang, } \\
\text { Tadikamalla, } \\
\text { Shang, and } \\
\text { Zhao } 2016\end{array}$ & $\begin{array}{l}\text { The study focuses on how } \\
\text { heterogeneous consumer in- } \\
\text { teractions in social media im- } \\
\text { pact brand adoption deci- } \\
\text { sions. }\end{array}$ & $\begin{array}{l}\text { An agent-based model is introduced } \\
\text { to replicate the evolution process of } \\
\text { market share for multiple brands } \\
\text { competing online. The model shows } \\
\text { among other things that electronic } \\
\text { word-of-mouth has a significant ef- } \\
\text { fect on online shoppers' buying deci- } \\
\text { sions and therefore on a brand's mar- } \\
\text { ket share. }\end{array}$ & $\begin{array}{l}\text { conceptual/ } \\
\text { simulation }\end{array}$ & na \\
\hline $\begin{array}{l}\text { Hothi, Saleena, } \\
\text { and Prakash } \\
2015\end{array}$ & $\begin{array}{l}\text { The paper investigates if } \\
\text { there is a link between a com- } \\
\text { pany's usage of Facebook and } \\
\text { company reputation. }\end{array}$ & $\begin{array}{l}\text { Interacting with users by posting rel- } \\
\text { evant updates on Facebook helps to } \\
\text { upgrade reputation. }\end{array}$ & $\begin{array}{l}\text { quantita- } \\
\text { tive }\end{array}$ & 7 \\
\hline $\begin{array}{l}\text { Gandhi, and } \\
\text { Muruganantham } \\
2015\end{array}$ & $\begin{array}{l}\text { The study investigates an ap- } \\
\text { proach to identify influencers } \\
\text { within social networks. }\end{array}$ & $\begin{array}{l}\text { A research framework is proposed to } \\
\text { estimate the influencers in a social } \\
\text { media site using Multi-Criteria Deci- } \\
\text { sion Making (MCDM) methods. }\end{array}$ & conceptual & na \\
\hline $\begin{array}{l}\text { Du, and Jiang } \\
2015\end{array}$ & $\begin{array}{l}\text { Is the usage of social media } \\
\text { associated with higher firm } \\
\text { performance as measured by } \\
\text { stock price and return on as- } \\
\text { sets? }\end{array}$ & $\begin{array}{l}\text { The study finds that firms with a so- } \\
\text { cial media presence are more highly } \\
\text { valued by the market and have higher } \\
\text { future financial performance and } \\
\text { therefore provides evidence of the } \\
\text { positive impact of social media tech- } \\
\text { nologies on firm performance. }\end{array}$ & $\begin{array}{l}\text { quantita- } \\
\text { tive }\end{array}$ & 1414 \\
\hline$\frac{\text { Kim, Lim, and }}{\text { Brymer } 2015}$ & $\begin{array}{l}\text { This paper investigates how } \\
\text { managing online reviews af- } \\
\text { fects hotel performance, } \\
\text { measured as the average daily }\end{array}$ & $\begin{array}{l}\text { The results indicate that overall rat- } \\
\text { ings are the most salient predictor of } \\
\text { hotel performance, followed by re- } \\
\text { sponse to negative comments. The } \\
\text { better the overall ratings and the }\end{array}$ & $\begin{array}{l}\text { quantita- } \\
\text { tive }\end{array}$ & 128 \\
\hline
\end{tabular}




\begin{tabular}{|c|c|c|c|c|}
\hline & $\begin{array}{l}\text { rate and revenue per available } \\
\text { room. }\end{array}$ & $\begin{array}{l}\text { higher the response rate to negative } \\
\text { comments, the higher the hotel per- } \\
\text { formance. }\end{array}$ & & \\
\hline $\begin{array}{l}\text { Kesting, and } \\
\text { Günzel-Jensen } \\
\underline{2015}\end{array}$ & $\begin{array}{l}\text { The paper investigates busi- } \\
\text { ness model sophistication as } \\
\text { a tool for new ventures and } \\
\text { SMEs to increase their pool } \\
\text { of resources and competitive- } \\
\text { ness. }\end{array}$ & $\begin{array}{l}\text { A framework is developed that intro- } \\
\text { duces five business model sophistica- } \\
\text { tion strategies, one of them being the } \\
\text { involvement of users and the crowd } \\
\text { through social media. }\end{array}$ & conceptual & na \\
\hline $\begin{array}{l}\text { Braojos-Gomez, } \\
\text { Benitez-Amado, } \\
\text { and Javier } \\
\text { Llorens-Montes } \\
2015\end{array}$ & $\begin{array}{l}\text { Investigates the variables } \\
\text { through which small firms } \\
\text { can learn to adopt social me- } \\
\text { dia. }\end{array}$ & $\begin{array}{l}\text { IT infrastructure capability, social } \\
\text { competitor pressure, marketing man- } \\
\text { agement and innovation management } \\
\text { are key mechanisms through which } \\
\text { small firms learn to develop a social } \\
\text { media competence. }\end{array}$ & $\begin{array}{l}\text { quantita- } \\
\text { tive }\end{array}$ & 100 \\
\hline $\begin{array}{l}\text { Harrigan, } \\
\text { Soutar, } \\
\text { Choudhury, and } \\
\text { Lowe } 2015\end{array}$ & $\begin{array}{l}\text { The paper investigates the } \\
\text { role of social media within } \\
\text { social CRM. }\end{array}$ & $\begin{array}{l}\text { Findings show that an underlying } \\
\text { customer relationship orientation is } \\
\text { needed to drive social media technol- } \\
\text { ogy use and customer engagement } \\
\text { initiatives. Customer relationship ori- } \\
\text { entation also has a direct impact on } \\
\text { customer relationship performance, } \\
\text { measured as the performance relative } \\
\text { to competitors in keeping current } \\
\text { customers. }\end{array}$ & $\begin{array}{l}\text { quantita- } \\
\text { tive }\end{array}$ & 159 \\
\hline $\begin{array}{l}\text { Tomaras, and } \\
\text { Ntalianis } 2015\end{array}$ & $\begin{array}{l}\text { The paper analyzes the im- } \\
\text { pact of advertisements on so- } \\
\text { cial media. }\end{array}$ & $\begin{array}{l}\text { A novel, unsupervised social compu- } \\
\text { ting approach is proposed, which al- } \\
\text { gorithmically estimates the im- } \\
\text { portance of each advertisement by } \\
\text { considering both explicit interactions } \\
\text { between advertisements and social } \\
\text { media users and users' popularity. }\end{array}$ & conceptual & na \\
\hline $\begin{array}{l}\text { Sun, Chen, and } \\
\text { Fan } 2014\end{array}$ & $\begin{array}{l}\text { The paper develops a model } \\
\text { to identify active and valua- } \\
\text { ble customers on social me- } \\
\text { dia to enable an efficient allo- } \\
\text { cation of marketing re- } \\
\text { sources. }\end{array}$ & $\begin{array}{l}\text { A framework for customer response } \\
\text { modeling in social media is devel- } \\
\text { oped. }\end{array}$ & qualitative & na \\
\hline $\begin{array}{l}\text { Martínez- } \\
\text { Núñez, and } \\
\text { Pérez-Aguiar } \\
2014\end{array}$ & $\begin{array}{l}\text { The paper introduces a model } \\
\text { to analyze the relationship } \\
\text { between the usage of online } \\
\text { social networks and produc- } \\
\text { tion efficiency, measured as } \\
\text { responses to social media } \\
\text { campaigns, sales, as well as } \\
\text { pre-tax profits. }\end{array}$ & $\begin{array}{l}\text { Results reveal that companies are } \\
\text { able to use social networks as a key } \\
\text { factor in improving their productive } \\
\text { efficiency. The newly developed } \\
\text { model is able to assess the strategic } \\
\text { performance of social networks. }\end{array}$ & $\begin{array}{l}\text { quantita- } \\
\text { tive }\end{array}$ & 149 \\
\hline $\begin{array}{l}\text { Jussila, } \\
\text { Kärkkäinen, and } \\
\text { Aramo- } \\
\text { Immonen } 2014\end{array}$ & $\begin{array}{l}\text { The paper investigates oppor- } \\
\text { tunities and challenges of so- } \\
\text { cial media use in industrial } \\
\text { business-to-business compa- } \\
\text { nies. }\end{array}$ & $\begin{array}{l}\text { There is a significant gap between } \\
\text { the perceived potential of social me- } \\
\text { dia and social media use with cus- } \\
\text { tomers and partners in business-to- } \\
\text { business companies. Potentially ef- } \\
\text { fective ways to reduce the gap are } \\
\text { identified. }\end{array}$ & $\begin{array}{l}\text { quantita- } \\
\text { tive }\end{array}$ & 125 \\
\hline $\begin{array}{l}\text { Wu, Lirn, and } \\
\text { Dong } 2014\end{array}$ & $\begin{array}{l}\text { This study investigates the } \\
\text { correlation between the } \\
\text { placement of corporate ads }\end{array}$ & $\begin{array}{l}\text { It was found that both page hit popu- } \\
\text { larity and target group agreement on }\end{array}$ & $\begin{array}{l}\text { quantita- } \\
\text { tive }\end{array}$ & $\begin{array}{l}\text { not dis- } \\
\text { closed }\end{array}$ \\
\hline
\end{tabular}




\begin{tabular}{|c|c|c|c|c|}
\hline & $\begin{array}{l}\text { on social media platforms } \\
\text { and sales performance. }\end{array}$ & $\begin{array}{l}\text { effective advertisement characteris- } \\
\text { tics relate positively to sales. }\end{array}$ & & \\
\hline Arman 2014 & $\begin{array}{l}\text { What is the state of research } \\
\text { in social media and CRM in- } \\
\text { tegration? }\end{array}$ & $\begin{array}{l}\text { Integration of social media and CRM } \\
\text { is imperative for organizations in } \\
\text { conducting business. More research } \\
\text { has to be conducted to blend the two } \\
\text { approaches. }\end{array}$ & conceptual & na \\
\hline $\begin{array}{l}\text { Trainor, } \\
\text { Andzulis, Rapp, } \\
\text { and Agnihotri } \\
2014\end{array}$ & $\begin{array}{l}\text { The study examines how so- } \\
\text { cial media technology usage } \\
\text { and customer-centric man- } \\
\text { agement systems contribute } \\
\text { to a firm-level capability of } \\
\text { social CRM. }\end{array}$ & $\begin{array}{l}\text { The study develops a way to concep- } \\
\text { tualize and measure social CRM ca- } \\
\text { pability. Further, it finds that both } \\
\text { customer-centric management sys- } \\
\text { tems and social media technologies } \\
\text { influence social CRM capability. } \\
\text { These two resources are found to } \\
\text { have an interactive effect on the for- } \\
\text { mation of a firm-level capability that } \\
\text { is shown to positively relate to cus- } \\
\text { tomer relationship performance. }\end{array}$ & $\begin{array}{l}\text { quantita- } \\
\text { tive }\end{array}$ & 308 \\
\hline $\begin{array}{l}\text { Paniagua, and } \\
\text { Sapena } 2014\end{array}$ & $\begin{array}{l}\text { The study explores the link } \\
\text { between resources generated } \\
\text { from social media sites and } \\
\text { business performance, meas- } \\
\text { ured as stock prices. }\end{array}$ & $\begin{array}{l}\text { Four channels are conceptualized by } \\
\text { which social media impacts financial, } \\
\text { operational, and corporate social per- } \\
\text { formance: social capital, customers' } \\
\text { revealed preferences, social market- } \\
\text { ing, and social corporate networking. } \\
\text { An empirical test of the framework } \\
\text { shows that "followers" and "likes" } \\
\text { positively influence a firm's share } \\
\text { value, but only after a critical mass of } \\
\text { followers is attained. }\end{array}$ & $\begin{array}{l}\text { quantita- } \\
\text { tive }\end{array}$ & 26 \\
\hline $\begin{array}{l}\text { Rodriguez, L. } \\
\text { Dixon, and W. } \\
\text { Peltier } 2014\end{array}$ & $\begin{array}{l}\text { The purpose of this study is } \\
\text { to summarize interactive mar- } \\
\text { keting literature in the con- } \\
\text { text of personal selling and } \\
\text { sales management. }\end{array}$ & $\begin{array}{l}\text { The use of social media platforms in } \\
\text { a professional selling context is re- } \\
\text { ceiving increased exposure in the lit- } \\
\text { erature. However, several research } \\
\text { questions are proposed, including } \\
\text { among others "How can salespeople } \\
\text { and the selling organization best uti- } \\
\text { lize evolving social media technolo- } \\
\text { gies?," "What are the most effective } \\
\text { strategies and tactics for enhancing } \\
\text { customer engagement?," "How might } \\
\text { sales managers use social media to } \\
\text { engage their sales force?," "Which } \\
\text { types of social media platforms are } \\
\text { most effective and at which stages in } \\
\text { the selling process?" }\end{array}$ & $\begin{array}{l}\text { content } \\
\text { analysis of } \\
\text { research } \\
\text { papers }\end{array}$ & 106 \\
\hline $\begin{array}{l}\text { Lau, Li, and } \\
\text { Liao } 2014\end{array}$ & $\begin{array}{l}\text { The paper investigates ways } \\
\text { to extract market intelligence } \\
\text { from social media platforms } \\
\text { to generate information to } \\
\text { improve product designs and } \\
\text { marketing strategies. }\end{array}$ & $\begin{array}{l}\text { A novel social analytics methodology } \\
\text { is designed that leverages large vol- } \\
\text { umes of consumer reviews archived } \\
\text { on social media sites to perform a } \\
\text { fine-grained extraction of market in- } \\
\text { telligence. }\end{array}$ & conceptual & na \\
\hline $\begin{array}{l}\text { Jiang, Chen, } \\
\text { Nunamaker, and } \\
\text { Zimbra } 2014\end{array}$ & $\begin{array}{l}\text { The paper explores ways to } \\
\text { identify and focus on the } \\
\text { most important stakeholders } \\
\text { within a social media content. }\end{array}$ & $\begin{array}{l}\text { A stakeholder-based event analysis } \\
\text { framework is proposed that segments } \\
\text { forum participants by stakeholder } \\
\text { groups and partitions their messages } \\
\text { into different time periods of major }\end{array}$ & $\begin{array}{l}\text { quantita- } \\
\text { tive }\end{array}$ & 6 \\
\hline
\end{tabular}




\begin{tabular}{|c|c|c|c|c|}
\hline & & $\begin{array}{l}\text { firm events. Results show that some } \\
\text { stakeholder groups identified by the } \\
\text { system had stronger relationships } \\
\text { with firms' market/stock perfor- } \\
\text { mance, compared to the entire set of } \\
\text { web forum participants. }\end{array}$ & & \\
\hline $\begin{array}{l}\text { Giannakis- } \\
\text { Bompolis, and } \\
\text { Boutsouki } 2014\end{array}$ & $\begin{array}{l}\text { The study attempts to esti- } \\
\text { mate the degree to which (tra- } \\
\text { ditional) CRM practices are } \\
\text { an effective tool to enable } \\
\text { customer/social engagement. }\end{array}$ & $\begin{array}{l}\text { Among other things, an active social } \\
\text { media presence can be considered a } \\
\text { significant determinant of customers' } \\
\text { willingness to get involved in a new } \\
\text { type of relationship with the com- } \\
\text { pany. }\end{array}$ & $\begin{array}{l}\text { quantita- } \\
\text { tive }\end{array}$ & 330 \\
\hline $\begin{array}{l}\text { Thoumrungroje } \\
2014\end{array}$ & $\begin{array}{l}\text { The paper proposes a model } \\
\text { linking the intensity of social } \\
\text { media use with consumers' } \\
\text { reliance on electronic word- } \\
\text { of-mouth (EWOM) and their } \\
\text { consumption of conspicuous } \\
\text { products. }\end{array}$ & $\begin{array}{l}\text { The results reveal both direct and in- } \\
\text { direct influences (i.e., via EWOM) of } \\
\text { social media intensity on conspicu- } \\
\text { ous consumption. Social media and } \\
\text { EWOM are effective tools for entic- } \\
\text { ing demand for conspicuous prod- } \\
\text { ucts. }\end{array}$ & $\begin{array}{l}\text { quantita- } \\
\text { tive }\end{array}$ & 1142 \\
\hline $\begin{array}{l}\text { Öztamur, and } \\
\text { Karakadilar } \\
2014\end{array}$ & $\begin{array}{l}\text { The paper analyzes how } \\
\text { SMEs engage with their cus- } \\
\text { tomers online and use social } \\
\text { media as a strategic tool of } \\
\text { social network marketing. } \\
\text { Performance is assessed in } \\
\text { terms of social media-inher- } \\
\text { ent measures such as unique } \\
\text { visitors, interaction rates, and } \\
\text { relevant actions taken. }\end{array}$ & $\begin{array}{l}\text { Using formal language during the } \\
\text { customer's communication process } \\
\text { and creating unattractive content } \\
\text { cause problems in social network } \\
\text { marketing. }\end{array}$ & qualitative & 4 \\
\hline $\begin{array}{l}\text { Jang, Sim, Lee, } \\
\text { and Kwon } 2013\end{array}$ & $\begin{array}{l}\text { The study investigates ways } \\
\text { how customer feedback on } \\
\text { social media can be effi- } \\
\text { ciently analyzed. }\end{array}$ & $\begin{array}{l}\text { An automated method of estimating } \\
\text { causality between user profiles, value } \\
\text { structures, and attitudes based on the } \\
\text { replies and published content man- } \\
\text { aged by open social network systems } \\
\text { is introduced. }\end{array}$ & conceptual & na \\
\hline $\begin{array}{l}\text { Fitzgerald, } \\
\text { Kruschwitz, } \\
\text { Bonnet, and } \\
\text { Welch } 2014\end{array}$ & $\begin{array}{l}\text { How do businesses succeed } \\
\text { or fail in using digital tech- } \\
\text { nology to improve business } \\
\text { performance, such as enhanc- } \\
\text { ing customer experience, } \\
\text { streamlining operations, or } \\
\text { creating new business mod- } \\
\text { els? }\end{array}$ & $\begin{array}{l}\text { The study identifies several com- } \\
\text { pany-internal challenges and oppor- } \\
\text { tunities firms are confronted with } \\
\text { when trying to realize the potential of } \\
\text { new technologies. }\end{array}$ & $\begin{array}{l}\text { quantita- } \\
\text { tive }\end{array}$ & 1559 \\
\hline $\begin{array}{l}\text { Pöyry, } \\
\text { Parvinen, and } \\
\text { Malmivaara } \\
2013\end{array}$ & $\begin{array}{l}\text { The study investigates con- } \\
\text { sumers' underlying motiva- } \\
\text { tions to use companies' social } \\
\text { networking sites and links } \\
\text { them with business success. }\end{array}$ & $\begin{array}{l}\text { This study distinguishes between } \\
\text { consumers' hedonic and utilitarian } \\
\text { motivations for using company- } \\
\text { hosted Facebook pages and relates } \\
\text { them to two types of community us- } \\
\text { age behavior: browsing and partici- } \\
\text { pation. Hedonic motivations indicate } \\
\text { a higher propensity to participate in } \\
\text { the community whereas utilitarian } \\
\text { motivations relate more strongly to } \\
\text { merely browsing the community } \\
\text { page. The participating members do } \\
\text { not display intentions to buy from the }\end{array}$ & $\begin{array}{l}\text { quantita- } \\
\text { tive }\end{array}$ & 1162 \\
\hline
\end{tabular}




\begin{tabular}{|c|c|c|c|c|}
\hline & & $\begin{array}{l}\text { host company or refer it to others, } \\
\text { while the browsers do. }\end{array}$ & & \\
\hline $\begin{array}{l}\text { Gecti, and } \\
\text { Dastan } 2013\end{array}$ & $\begin{array}{l}\text { The study investigates the ef- } \\
\text { fects of social media usage on } \\
\text { business turnover. }\end{array}$ & $\begin{array}{l}\text { Social media usage positively affects } \\
\text { business performance. Two variables } \\
\text { mediate this link: (marketing) cost } \\
\text { savings and marketing-based outputs, } \\
\text { such as increased brand recognition } \\
\text { and customer loyalty. }\end{array}$ & $\begin{array}{l}\text { quantita- } \\
\text { tive }\end{array}$ & 152 \\
\hline $\begin{array}{l}\text { Malthouse, } \\
\text { Haenlein, } \\
\text { Skiera, Wege, } \\
\text { and Zhang } 2013\end{array}$ & $\begin{array}{l}\text { The paper examines how } \\
\text { CRM needs to adapt to the } \\
\text { rise of social media. }\end{array}$ & $\begin{array}{l}\text { The concept of the "social CRM } \\
\text { house" is introduced, followed by a } \\
\text { discussion on how social media en- } \\
\text { gagement affects the house's core ar- } \\
\text { eas (i.e. acquisition, retention, and } \\
\text { termination) and supporting business } \\
\text { areas (i.e. people, IT, performance } \\
\text { evaluation, metrics and overall mar- } \\
\text { keting strategy). }\end{array}$ & conceptual & na \\
\hline $\begin{array}{l}\text { Rapp, } \\
\text { Beitelspacher, } \\
\text { Grewal, and } \\
\text { Hughes } 2013\end{array}$ & $\begin{array}{l}\text { The study investigates social } \\
\text { media contagion effects } \\
\text { across business suppliers, re- } \\
\text { tailers, and consumers and } \\
\text { their impact on multiple per- } \\
\text { formance measures such as } \\
\text { brand performance, retailer } \\
\text { performance, and consumer- } \\
\text { retailer loyalty. }\end{array}$ & $\begin{array}{l}\text { Social media use positively contrib- } \\
\text { utes to brand performance, retailer } \\
\text { performance, and consumer-retailer } \\
\text { loyalty. The effect of supplier social } \\
\text { media usage on retailer social media } \\
\text { usage and in turn on customer social } \\
\text { media usage is moderated by brand } \\
\text { reputation and service ambidexterity. } \\
\text { The study provides a framework to } \\
\text { promote usage by supply channel } \\
\text { partners which ultimately influences } \\
\text { performance-related outcomes. }\end{array}$ & $\begin{array}{l}\text { quantita- } \\
\text { tive }\end{array}$ & 617 \\
\hline $\begin{array}{l}\text { Gensler, } \\
\text { Völckner, Liu- } \\
\text { Thompkins, and } \\
\text { Wiertz } 2013\end{array}$ & $\begin{array}{l}\text { The study investigates key } \\
\text { challenges related to manag- } \\
\text { ing brands in social media en- } \\
\text { vironments. }\end{array}$ & $\begin{array}{l}\text { A framework of social media's im- } \\
\text { pact on brand management is intro- } \\
\text { duced. Among other things it argues } \\
\text { that consumers are becoming pivotal } \\
\text { authors of brand stories due to new, } \\
\text { dynamic networks of consumers and } \\
\text { brands formed through social media } \\
\text { and the easy sharing of brand experi- } \\
\text { ences in such networks. Key research } \\
\text { questions are identified. }\end{array}$ & conceptual & na \\
\hline $\begin{array}{l}\text { Carim, and } \\
\text { Warwick } 2013\end{array}$ & $\begin{array}{l}\text { Explores the use of social } \\
\text { media as a communications } \\
\text { tool. }\end{array}$ & $\begin{array}{l}\text { Most sample firms have adopted so- } \\
\text { cial media, building a dialogue with } \\
\text { stakeholders is a prime reason for us- } \\
\text { ing social channels, although one- } \\
\text { way "broadcasting" of information is } \\
\text { widespread. }\end{array}$ & $\begin{array}{l}\text { quantita- } \\
\text { tive }\end{array}$ & 111 \\
\hline $\begin{array}{l}\text { Qu, Wang, } \\
\text { Wang, and } \\
\text { Zhang 2013 }\end{array}$ & $\begin{array}{l}\text { This study investigates } \\
\text { whether online retailers' so- } \\
\text { cial activity on e-commerce } \\
\text { platforms improves their } \\
\text { business performance, and if } \\
\text { so, aims to identify the under- } \\
\text { lying mechanisms. Business } \\
\text { performance is measured as } \\
\text { revenue and transaction vol- } \\
\text { ume. }\end{array}$ & $\begin{array}{l}\text { Online retailers' social activities for } \\
\text { friend-making improve their business } \\
\text { performance, regardless of the direc- } \\
\text { tional attribute of the activities. So- } \\
\text { cial activities for advice-seeking de- } \\
\text { crease online retailers' business per- } \\
\text { formance. Social activities for ad- } \\
\text { vice-giving increase online retailers' } \\
\text { business performance. }\end{array}$ & $\begin{array}{l}\text { quantita- } \\
\text { tive }\end{array}$ & 7380 \\
\hline
\end{tabular}




\begin{tabular}{|c|c|c|c|c|}
\hline $\begin{array}{l}\text { Nickell, Rollins, } \\
\text { and Hellman } \\
2013\end{array}$ & $\begin{array}{l}\text { The study aims to investigate } \\
\text { the marketing actions that } \\
\text { companies performed during } \\
\text { the recession of the late } \\
2000 \text { s and the resulting effect } \\
\text { on firm performance, meas- } \\
\text { ured as profits, sales growth, } \\
\text { market share, and cash flow. }\end{array}$ & $\begin{array}{l}\text { All companies in the sample report } \\
\text { an increase in their use of digital } \\
\text { marketing during the recession. Busi- } \\
\text { ness-to-business companies have re- } \\
\text { sponded to digital marketing slower } \\
\text { than consumer companies. However, } \\
\text { "social media use" does not discrimi- } \\
\text { nate between high and low perform- } \\
\text { ing firms. }\end{array}$ & $\begin{array}{l}\text { quantita- } \\
\text { tive }\end{array}$ & 190 \\
\hline $\begin{array}{l}\text { Schniederjans, } \\
\text { Cao, and } \\
\text { Schniederjans } \\
2013\end{array}$ & $\begin{array}{l}\text { The paper addresses social } \\
\text { media as a platform within } \\
\text { impression management and } \\
\text { asks if social media impact a } \\
\text { firm's financial performance, } \\
\text { measured as stock returns. } \\
\text { The types of social media } \\
\text { strategies that impact a firm's } \\
\text { financial performance are } \\
\text { also explored. }\end{array}$ & $\begin{array}{l}\text { Social media usage, as part of a com- } \\
\text { pany's impression management, } \\
\text { leads to increased financial perfor- } \\
\text { mance if strategies of ingratiation, in- } \\
\text { timidation, organizational promotion } \\
\text { and supplication are followed. }\end{array}$ & $\begin{array}{l}\text { quantita- } \\
\text { tive }\end{array}$ & 150 \\
\hline $\begin{array}{l}\text { Yu, Duan, and } \\
\text { Cao } 2013\end{array}$ & $\begin{array}{l}\text { The study investigates the ef- } \\
\text { fect of social media and con- } \\
\text { ventional media, their relative } \\
\text { importance, and their interre- } \\
\text { latedness with short-term } \\
\text { firm stock market perfor- } \\
\text { mances. }\end{array}$ & $\begin{array}{l}\text { Overall, social media has a stronger } \\
\text { relationship with firm stock perfor- } \\
\text { mance than conventional media. So- } \\
\text { cial and conventional media have a } \\
\text { strong interaction effect on stock per- } \\
\text { formance. Also, the impact of differ- } \\
\text { ent types of social media varies sig- } \\
\text { nificantly. Different types of social } \\
\text { media also interrelate with conven- } \\
\text { tional media to influence stock } \\
\text { movement in various directions and } \\
\text { degrees. }\end{array}$ & $\begin{array}{l}\text { quantita- } \\
\text { tive }\end{array}$ & 824 \\
\hline $\begin{array}{l}\text { Schultz, } \\
\text { Schwepker, and } \\
\text { Good } 2012 \\
\end{array}$ & $\begin{array}{l}\text { This paper proposes and em- } \\
\text { pirically assesses a model of } \\
\text { social media usage among } \\
\text { business-to-business (B2B) } \\
\text { salespeople. Performance is } \\
\text { assessed through measures } \\
\text { such as sales, profits, and } \\
\text { customer acquisition. }\end{array}$ & $\begin{array}{l}\text { Age of the salesperson negatively af- } \\
\text { fects social media usage, while social } \\
\text { media norms positively affect it. So- } \\
\text { cial media usage positively affects } \\
\text { sales performance. Customer-ori- } \\
\text { ented selling, although not found to } \\
\text { be positively related to social media } \\
\text { usage, does have a positive effect on } \\
\text { sales performance. }\end{array}$ & $\begin{array}{l}\text { quantita- } \\
\text { tive }\end{array}$ & 273 \\
\hline
\end{tabular}

